\title{
WATER RESOURCES OF THE MYAKKA RIVER BASIN AREA, SOUTHWEST FLORIDA
}
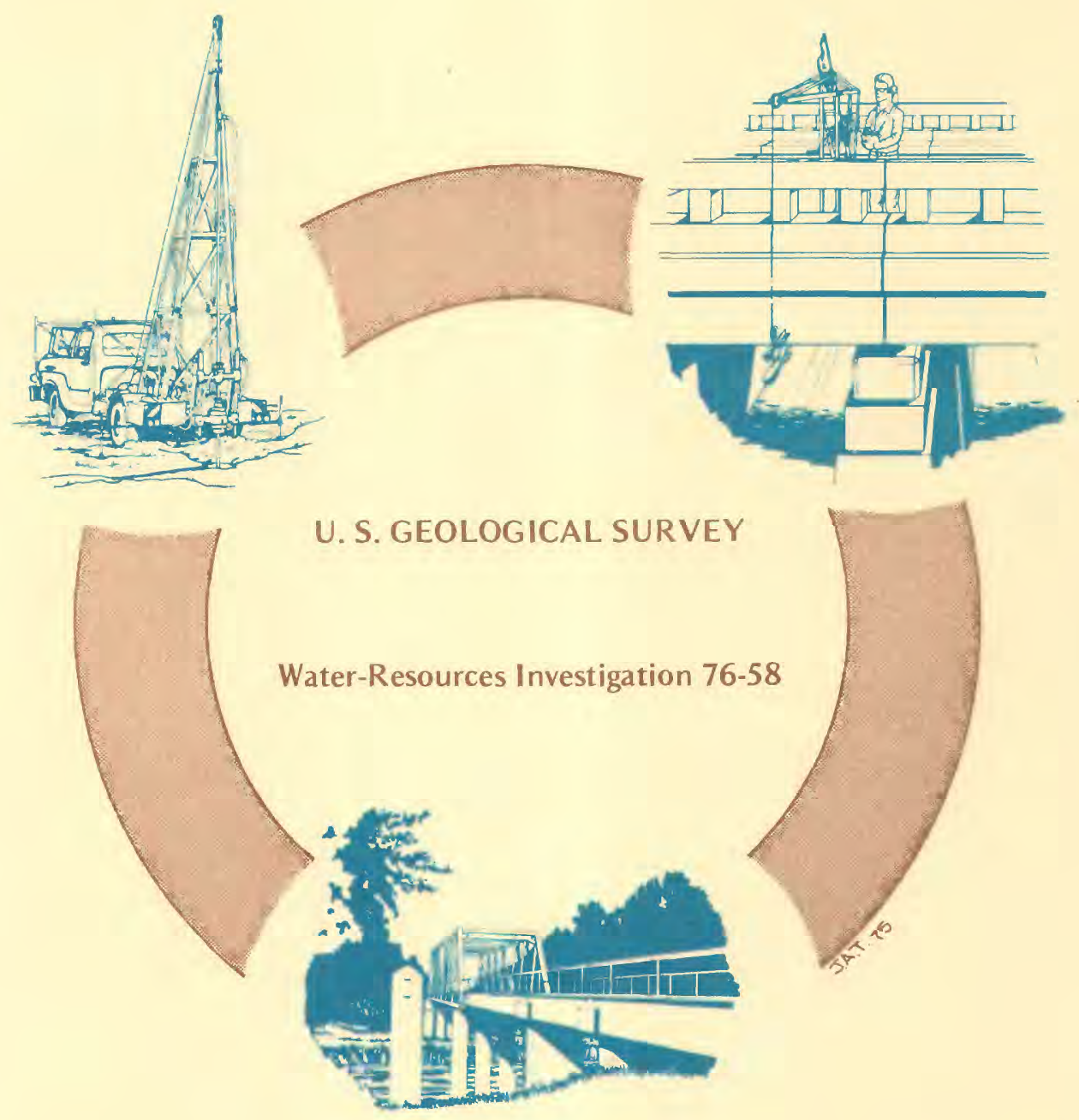

Prepared in cooperation with the BUREAU OF GEOLOGY, FLORIDA DEPARTMENT OF NATURAL RESOURCES, SARASOTA COUNTY, CITY OF SARASOTA, and the FLORIDA DEPARTMENT OF ENVIRONMENTAL REGULATION 


\begin{tabular}{|c|c|c|}
\hline & 1. Report No. & 3. Reci \\
\hline \multirow{2}{*}{\multicolumn{2}{|c|}{$\begin{array}{l}\text { 4. Title and Subtute WATER RESOURCES OF THE MYAKKA RIVER BASIN } \\
\text { AREA, SOUTHWEST FLORIDA }\end{array}$}} & $\begin{array}{l}\text { 5. Report Date } \\
\text { December } 1976\end{array}$ \\
\hline & & 6. \\
\hline \multicolumn{2}{|c|}{ 7. Author(s) B. F. Joyner and H. Sutcliffe, Jr. } & USGS/WRI I \\
\hline \multirow{2}{*}{\multicolumn{2}{|c|}{$\begin{array}{l}\text { 9. Performing Organization Name and Address } \\
\text { U.S. Geological Survey, Water Resources Division } \\
325 \text { John Knox Road } \\
\text { Suite F- } 240 \\
\text { Tallahassee, Florida } 32303\end{array}$}} & 10. Proje \\
\hline & & 11. Contract/Grant No. \\
\hline \multirow{2}{*}{\multicolumn{2}{|c|}{$\begin{array}{l}\text { 12. Sponsoring Organization Name and Address } \\
\text { U.S. Geological Survey, Water Resources Division } \\
325 \text { John Knox Road } \\
\text { Suite F- } 240 \\
\text { Tallahassee, Florida } 32303 \\
\end{array}$}} & $\begin{array}{l}\text { 13. Type of Report } \\
\text { Covered } \\
\text { Final }\end{array}$ \\
\hline & & 14. \\
\hline \multicolumn{3}{|c|}{ 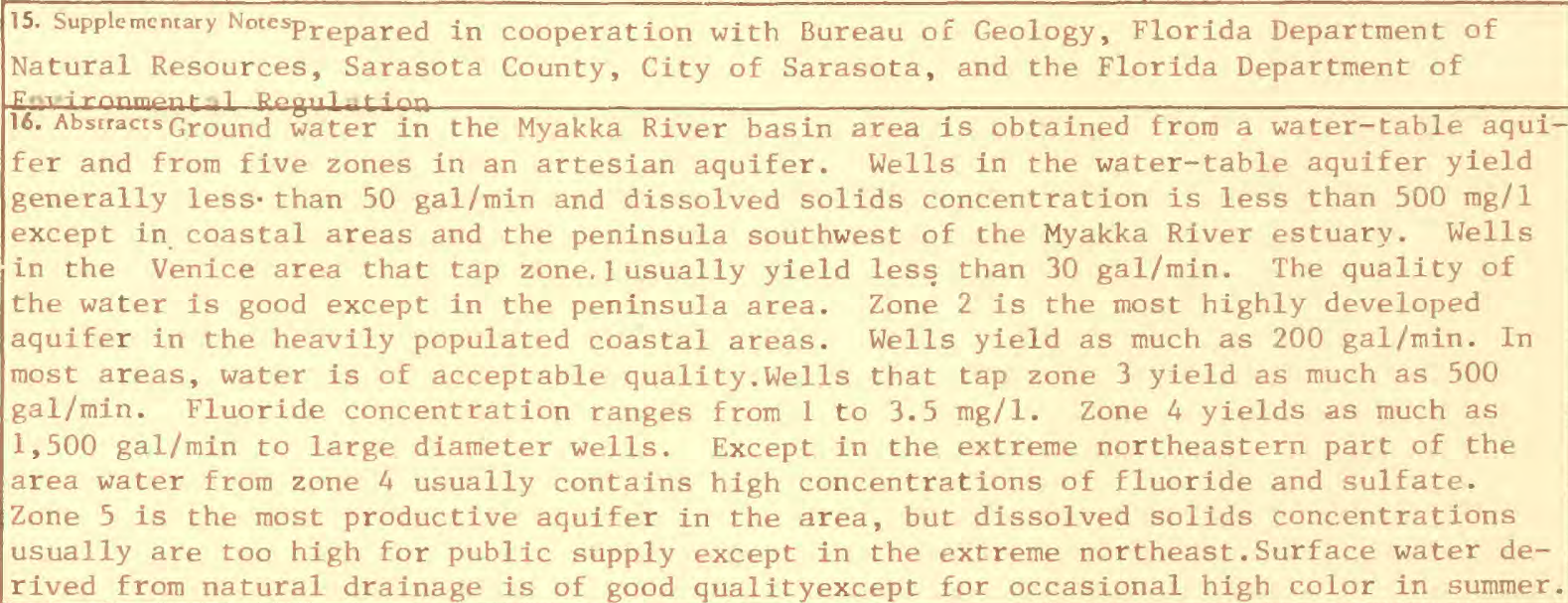 } \\
\hline
\end{tabular}

17b. Identifiers/Open-Ended Terms

*Zones, *Water problems, Sand, Clay, Tampa, Limestone, *Suwannee Limestone, Ocala Limestone, Hawthorn Formation, Avon Park. Formation, Venice Clay

17c. COSATI Field/Group

18. Availability Statement

No restriction on distribution.

\begin{tabular}{|c|c|}
\hline $\begin{array}{l}\text { 19. Security Class (This } \\
\text { Report) } \\
\text { (Niv) AsSIF IID }\end{array}$ & $\begin{array}{l}\text { 21. No. of Pages } \\
87\end{array}$ \\
\hline $\begin{array}{l}\text { 20. Security Class (This } \\
\text { Page } \\
\text { UNCI.ASSIFIFD }\end{array}$ & 22. Price \\
\hline
\end{tabular}


WATER RESOURCES OF THE MYAKKA RIVER

BASIN AREA, SOUTHWEST FLORIDA

By B. F. Joyner and H. Sutcliffe, Jr.

U.S. GEOLOGICAL SURVEY

Water-Resources Investigations 76-58

Prepared in cooperation with the

BUREAU OF GEOLOGY, FLORIDA DEPARTMENT OF NATURAL RESOURCES, SARASOTA COUNTY, CITY OF SARASOTA, and the

FLORIDA DEPARTMENT OF ENVIRONMENTAL REGULATION 
UNITED STATES DEPARTMENT OF THE INTERIOR

Thomas S. Kleppe, Secretary

GEOLOGICAL SURVEY

V. E. McKelvey, Director

For additional information write to:

U.S. Geological Survey

325 Jotum Rmox Roand

Suite $\mathbf{F}-240$

Tallahassee, Fllorilda 32303 
Abstract. . . . . . . . . . . . . . . . . . . . 1

Introduction. . . . . . . . . . . . . . . . . . 5

Purpose and scope. . . . . . . . . . . . . . . . 5

Acknowledgments. . . . . . . . . . . . . . . . 6

Previous investigations. . . . . . . . . . . . . 7

Description of the area . . . . . . . . . . . . . . 8

Location . . . . . . . . . . . . . . . . . . 8

Topography and drainage. . . . . . . . . . . . . . 8

Hydrology . . . . . . . . . . . . . . . . . . . . . 12

Rainfall and evapotranspiration. . . . . . . . . . 13

Ground water . . . . . . . . . . . . . . . . 17

Geologic and hydrogeologic units. . . . . . . . . 17

Water-table aquifer ... . . . . . . . . . 20

The artesian aquifer system. . . . . . . . . . . . . 31

Artesian zone-1.................. . 32

Artesian zone-2... . . . . . . . . . . . . 35

Artesian zone-3... . . . . . . . . . . . . 41

Artesian zone-4... . . . . . . . . . . . . 44

Artesian zone-5 . . . . . . . . . . . . . 49

Potentiometric surface. . . . . . . . . . . . 56

Surface water. . . . . . . . . . . . . . . . 59

Streamflow. . . . . . . . . . . . . . . 59

Water quality .. . . . . . . . . . . . 61

Lakes . . . . . . . . . . . . . . . . 64

Springs . . . . . . . . . . . . . . . 65

Water use .. . . . . . . . . . . . . . . . . 67

Water problems. . . . . . . . . . . . . . . . . 72

Floods . . . . . . . . . . . . . . . . . . 73

Drainage . . . . . . . . . . . . . . . . . . 74

Supply . . . . . . . . . . . . . . . . . . 75

Contamination. . . . . . . . . . . . . . . 76

Summary . . . . . . . . . . . . . . . . . . . 79

Selected references . . . . . . . . . . . . . . . 83

\section{ILLUSTRATIONS}

Figure 1.--Map showing location of Myakka River basin area. . . . 9

2.--Map of Myakka River basin area showing principal topographic and drainage features . . . . . . . . 10

3.--Graphs showing annual and mean monthly rainfall in the Myakka River basin area . . . . . . . . . . . . . 14

4.--Generalized sections $A-A^{\prime}, B-B^{\prime}, C-C^{\prime}$ and $D^{\prime} D^{\prime}$ showing 1ithologic units of 0ligocene age and younger, underlying the Myakka River basin area . . . 


\section{ILLUSTRATIONS (Continued)}

Page

Figure 5.--Generalized sections E-E', F-F', and G-G' showing lithologic units of Oligocene age and younger, underlying the Myakka River basin area . . .

6.--Map showing location of wells referred to in this report and lines of sections . . . . . . . . . .

7.--Hydrographs of selected observation wells tapping the water-table aquifer . . . . . . . . . . . 27

8.--Diagrams showing chemical quality of water from wells tapping the water-table aquifer . . . . . . .

9.--Hydrographs of selected observation wells tapping Zone-2. . . . . . . . . . . . . . . . .

10.--Diagrams showing chemical quality of water from wells tapping Zone 2 . . . . . . . . . . .

11.--Diagrams showing chemical quality of water from we11s tapping Zone 3. . . . . . . . . . . . . . .

12.--Hydrographs of selected observation we11s tapping Zones 2, 3, 4, and 5. . . . . . . . . . .

13.--Diagrams showing chemical quality of water from Zone 4 and composite chemical quality of water from Zones 2, 3, and 4. . . . . . . . . . . . . .

14.--Diagrams showing composite chemical quality of water from Zones $2,3,4$, and 5, and Warm Salt Springs . . . . . . . . . . . . . .

15.--Map showing generalized configuration of composite potentiometric surface of Zones 2, 3 , 4, and 5 in June 1966 . . . . . . . . . . . .

16.--Map showing generalized configuration of composite potentiometric surface of Zones 2, 3, 4, and 5 in November 1966 and area of artesian flow.

17.--Map showing surface-water sampling sites . . . . . .

18.--Graph of pumpage for the cities of Sarasota

\section{TABLES}

Table 1.--Geologic units penetrated by water wells in the Myakka River basin area. . . . . . . . . . . . . . 18

2.--Zonal subdivisions of the artesian aquifer system underlying the Myakka River basin area . . . . . . . . 19

3.--Analyses of water obtained from two wells that tap Zone 1 in Englewood and Venice area. . . . . . .

4.--Analyses of water obtained from a well that taps Zones 2, 3, and 4 . . . . . . . . . . . . . 
Table 5.--Analyses of water from Warm Salt Spring and well 5. . .

6.--Range in quality of surface water in the Myakka River basin area.............. 62

7.--Estimated ground-water use in the Myakka River basin area in 1965 ............... . . 68

For use of those readers who may prefer to use metric units rather than English units, the conversion factors for the terms used in this report are listed below

Multiply English unit

inch (in)

foot ( $f t$ )

mile (mi)

square mile $\left(\mathrm{mi}^{2}\right)$

acre

acre-foot (acre-ft)

gallon (gal)

gallon per minute (gal/min)

million gallons per day (Mgal/d)

cubic feet per second $\left(\mathrm{ft}^{3} / \mathrm{s}\right)$
By

25.4

.3048

1.609

2.590

.4047

.001233

3.785

.06309

.04381

.02832
To obtain metric unit

millimetre (mm)

metre (m)

kilometre $(\mathrm{km})$

square kilometre $\left(\mathrm{km}^{2}\right)$

hectare (ha)

cubic hectometre $\left(\mathrm{hm}^{3}\right)$

litre (1)

litres per second ( $1 / \mathrm{s})$

cubic metres per second $\left(\mathrm{m}^{3} / \mathrm{s}\right)$

cubic metres per second $\left(\mathrm{m}^{3} / \mathrm{s}\right)$

o 
WATER RESOURCES OF THE MYAKKA RIVER BASIN AREA,

SOUTHWEST FLORIDA

By

B. F. Joyner and H. Sutcliffe, Jr.

ABSTRACT

The Myakka River basin area covers about 1,120 square miles $(2,900$ square kilometres) and includes all of Sarasota County, and parts of Manatee, Charlotte, Hardee, and DeSoto Counties. Most of the area is less than 100 feet (30 metres) above mean sea level. Drainage is poor in much of the area and there are many swamps along the poorly defined stream channels.

Ground water in the Myakka River basin area is obtained from a watertable aquifer and.an artesian aquifer system consisting of several parts, referred to in this report as zones 1 through 5 . The watertable aquifer is composed of layers of sand, she11, marl and phosphate grave1, intermixed locally with sandy clay. The five zones of the artesian aquifer are as follows: (1) zone-1, semi-consolidated shell, clay, and limestone beds usually at depths less than 70 feet (21 metres) and best defined in the Venice area; (2) zone-2, consolidated clay, sandstone, and limestone of the upper unit of the Hawthorn Formation below a clay layer, which is present only in the coastal area, at depths of about 200 feet (61 metres); (3) zone-3, consolidated clay, limestone, and sandy limestone of the lower 60 to 80 feet (18 to 24 metres) of the Hawthorn Formation and upper part of the Tampa Limestone at depths ranging from 250 to 450 feet (75 to 140 metres); (4) zone-4, the lower part of the Tampa Limestone, Suwannee Limestone and the upper part of the Ocala Limestone between 500 and 700 feet in depth (150 to 
210 metres); and (5) zone-5, dense dolomitic limestone and dolomite of the Avon Park Limestone at depths of 1,000 to 1,500 feet (305 to 460 metres) below land surface.

We1ls in the water-table aquifer usually yield less than 50 gallons per minute (3.2 1itres per second). The dissolved solids concentration of the water is usually less than 500 milligrams per litre, except in coastal areas and the peninsula west of the Myakka River estuary where the the water is highly mineralized.

Yields from wells tapping zone-1 are usually no greater than 30 gallons per minute (2 1itres per second) in the Venice area. The quality of zone-1 water is good except in the peninsula southwest of the Myakka River estuary where the water also is highly mineralized. Water color is sometimes high, especially where direct recharge occurs through beds containing organic materials.

Zone-2 is the most highly developed aquifer in the heavily populated coastal areas. Yields as great as 200 gallons per minute (13 1itres per second) can be obtained from wells that penetrate all of zone-2. In most areas, water of acceptable quality can be obtained from zone-2. However, the fluoride or sulfate concentrations in the water from some wells often exceeds recommended limits for drinking water in the area. Chloride concentrations as high as 15,600 milligrams per 1itre occur in the peninsula southwest of the Myakka River estuary. 
Wells tapping zone- 3 yield as much as 500 gallons (1,900 1itres) per minute. The fluoride concentrations are usually high, ranging from about 1.0 to 3.5 milligrams per 1itre. Concentrations of sulfate in water from zone 3 often are high in the southern half of the area. Zone -4 yields as much as 1,500 gallons $(5,700$ litres) per minute to large diameter we11s. Except in the extreme northeastern part of the area the water from zone-4 usually contains high concentrations of fluoride and sulfate.

Zone -5 is the most productive aquifer in the area, but the water is usually too highly mineralized for public supply except in the extreme northeastern part of the area. The mineralization is sufficiently low, however, that the water can be used for irrigation purposes or condenser cooling.

Many non-tidal reaches of streams virtually go dry during the late spring of most years. Floods occur frequently, especially in low-1ying areas, but most of the water runs off and cannot be utilized because of a lack of storage.

Surface water derived from natural drainage is of good quality during normal and high flows, except for the occasional occurrence of high color and temperatures of about $32^{\circ} \mathrm{C}\left(90^{\circ} \mathrm{F}\right)$ during the summer. Low stream flows are often supplemented by waters having a high dissolvedconcentration derived from irrigation wells and domestic wastes. 
Use of ground water in 1965 is estimated to have averaged about 45 million gallons $(170,000$ cubic metres) per day for municipal, industrial, domestic and irrigation purposes. Use of surface water is estimated to have been about 2.5 million gallons $(9,500$ cubic metres:) per day for public water supply and pasture irrigation.

Water problems in the Myakka area include flooding, excessive drainage, inadequate supply of water of suitable quality, pollution and saltwater intrusion. 


\section{INTRODUCTION}

\section{Purpose and Scope}

The purpose of this report is to describe the occurrence and quality of surface and ground water in the Myakka River Basin area, to report the amount of ground water used as of 1965, and to define current and potential water-resources problems. Although this report presents information about the distribution and variability in the quantity and quality of the water resources, the major emphasis is on the ground-water resources. The report provides background data needed for use in planning more detailed quantitative studies of specific problems. The investigation upon which the report is based began in 1963 under a cooperative program between the Florida Bureau of Geology and the U.S. Geological Survey, later supplemented by the city of Sarasota and Sarasota County. Finalization of the report was supported by the Florida Department of Environmental Regulation.

Stage and discharge records from 54 streamflow stations and records of about 400 wells were collected during 1963-66. The well data include records of water levels, discharge, well construction, and driller and geophysical logs. Twenty-one test wells were drilled as part of the investigation in cooperation with Sarasota County. Water samples were collected for chemical analysis from streams and lakes and from wells. Information on water used for agricultural, industrial, and public supply purposes was obtained from an inventory made in 1965. 


\section{Acknowledgments}

The authors express their appreciation to the many residents of the area who freely gave information about their wells, and to various public officials, particularly the Sarasota County Commissioners and the city of Sarasota. Acknowledgment is made of the cooperation received from Smalley, Wellford and Nalven, consulting engineers to Sarasota County. Recognition is also expressed to the Sarasota County Agricultural Extension Agent and the Health Departments of Sarasota and Manatee Counties for their enthusiastic interest and cooperation. Information on irrigation of croplands in Sarasota County was furnished by Mr. Jack Zilles, U. S. Soil Conservation Service, and for Manatee County by Mr. Thomas Greenawalt, County Agricultural Extension Agent.

The Sarasota County Board of Public Instruction, General Development Corporation, Florida Department of Transportation, Manatee County Highway Department, and Mr. Albert Blackburn gave permission to drill and maintain observation wells on their properties. Several well drillers furnished geologic and hydrologic data, permitted collection of water samples and rock cuttings, and made measurements of water levels during drilling operations; grove owners and ranchers furnished data on water use for irrigation. 


\section{Previous Investigations}

The water resources of the area are described in numerous publications. Stringfield (1933) made a brief investigation of the groundwater resources of Sarasota County in 1931 and 1932. Peek (1958) investigated the ground-water resources of Manatee County and measured the water levels in many wells in Sarasota County during his study. Bishop (1960) reported on the fresh-water resources of Sarasota County. Smith and Gillespie (1960), consulting engineers, prepared an interim report on ground water for the city of Sarasota. Smalley, Wellford, and Nalvern (1961 and 1963) consulting engineers, prepared two reports for the Sarasota County Commissioners. Flippo and Joyner (1968) described the low-flow characteristics of streams in the basin. A brief summary of their findings is presented in this report.

Other investigators have included parts of the Myakka River basin area in geologic and hydrologic studies. Stringfield (1966) reported on artesian water in Tertiary limestone in the southeastern United States. Collins and Howard (1928), B1ack and Brown (1951), Wander and Reitz (1951), and the Florida State Board of Health (1960, 1964) give information about the chemical quality of water in the area. The reference list at the end of this report includes other investigations for the area. 


\section{DESCRIPTION OF THE AREA}

\section{Location}

The Myakka River basin area covers about $1,000 \mathrm{mi}^{2}\left(2,590 \mathrm{~km}^{2}\right)$ of 1 and and about $120 \mathrm{mi}^{2}\left(310 \mathrm{~km}^{2}\right)$ of bays and keys bordering the Gulf of Mexico in southwestern Florida (fig. 1). The area includes a11 of the Myakka River basin, part of the Peace River basin north of Charlotte Harbor, and about 20 sma11 coastal basins and keys between Charlotte Harbor and the city of Sarasota. The north and east boundaries are roughly coincident with the Myakka River basin drainage divide.

\section{Topography and Drainage}

Most of the Myakka River basin area is in the Coastal Lowlands topographic region of Florida (Cooke, 1945, p. 8), in the Atlantic Coastal Plain Province. About $11 \mathrm{mi}^{2}\left(29 \mathrm{~km}^{2}\right)$ in the extreme headwaters of the Myakka River basin is in the Central Highlands region.

The topography of the area is characterized by a series of gently sloping marine terraces which were developed during former stages of sea level. Maximum altitude is $116 \mathrm{ft}(35 \mathrm{~m})$ in the northeast part of the area where the oldest terraces have been dissected into low rolling hills. The southwestern half of the area is less than $20 \mathrm{ft}(6 \mathrm{~m})$ above sea level (fig 2) and has little local relief.

The 1arger streams anc canals that make up the drainage system of the Myakka River basin area are shown in figure 2. The natural stream channels form a poorly developed drainage system. Large swampy areas border many channels. 


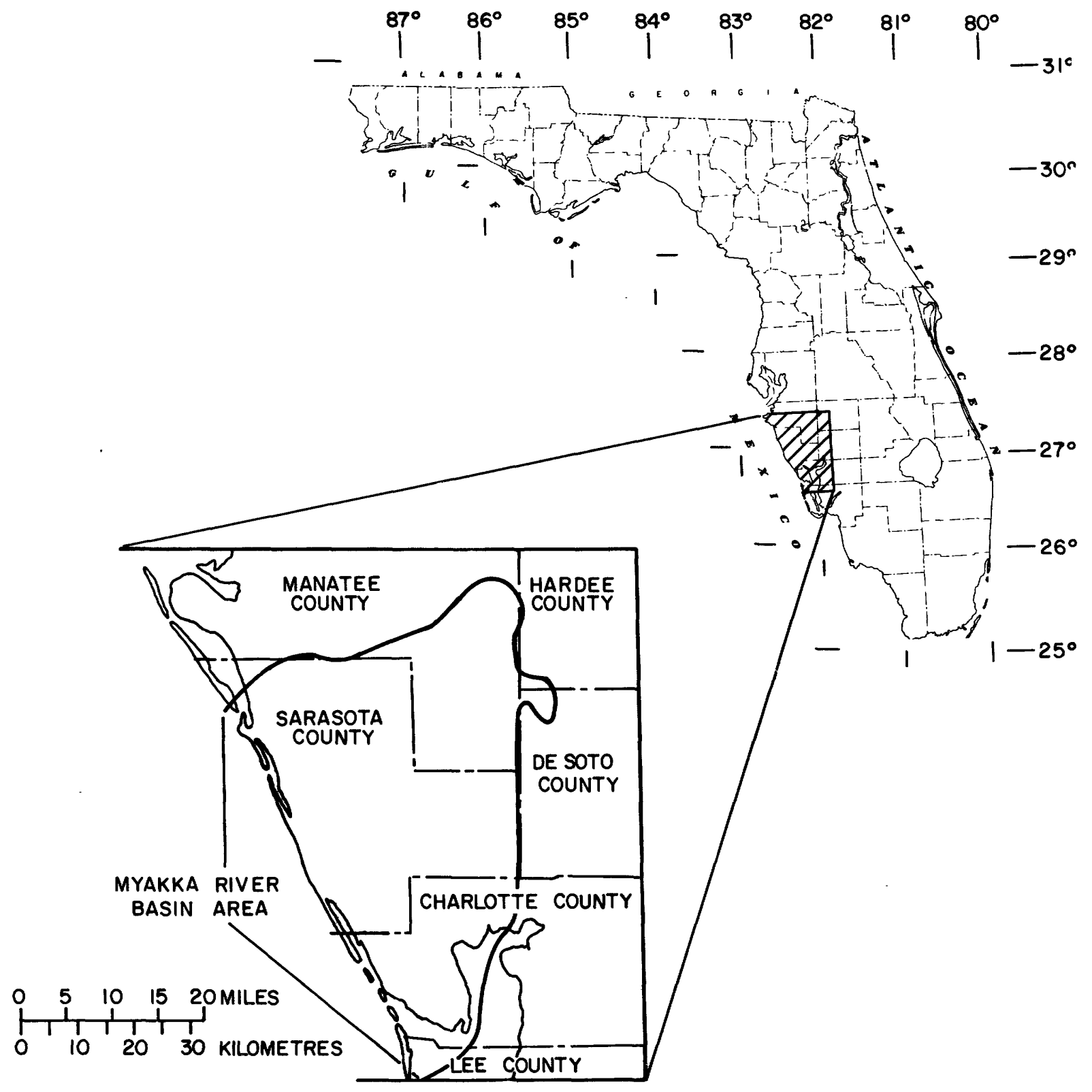

FIGURE 1,--LOCATION OF MYAKKA RIVER BASIN AREA, 


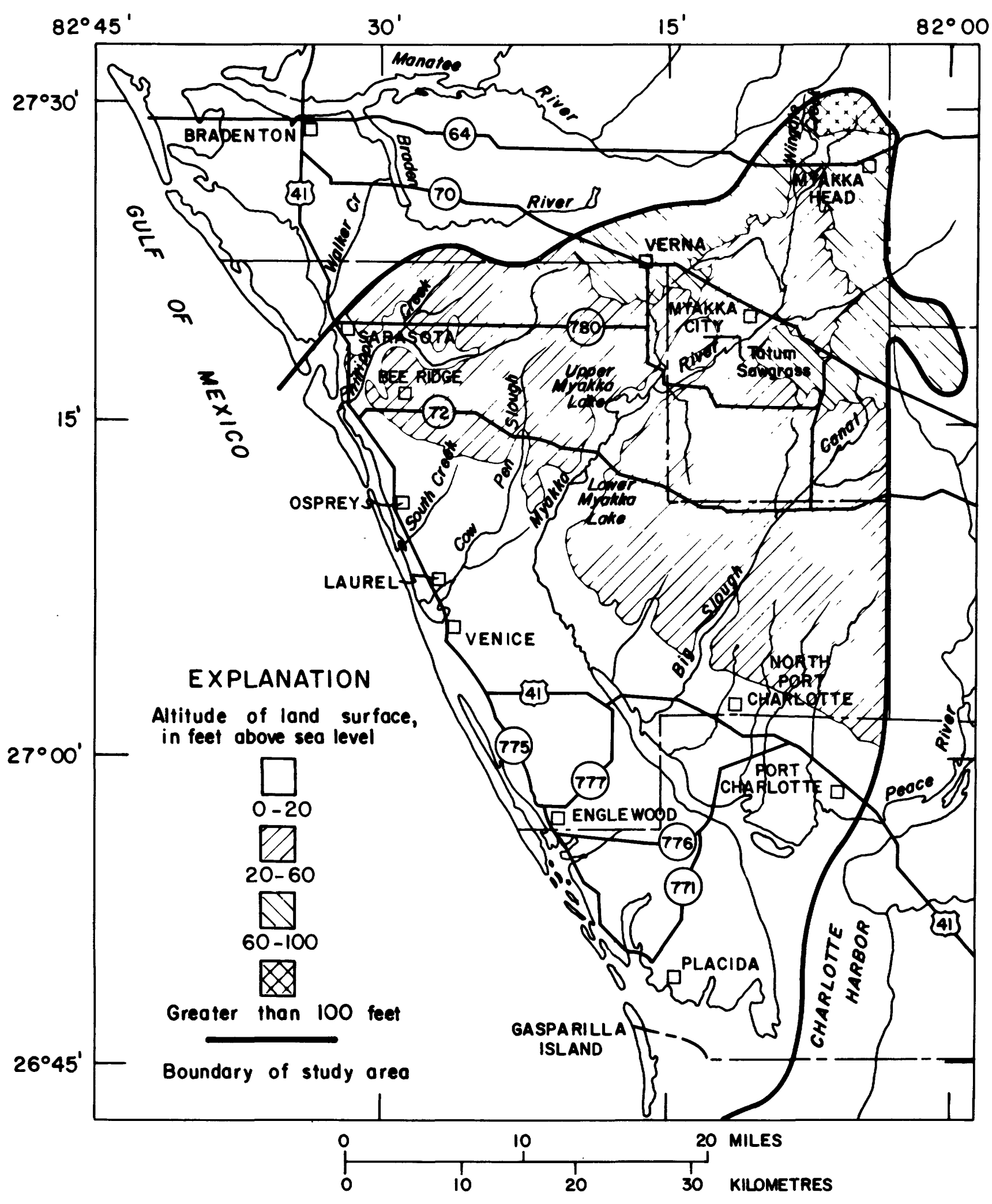

FIGURE 2,--PRINCIPAL TOPOGRAPHIC AND DRAINAGE FEATURES, 
In the broad flatlands most natural drainageways are shallow sloughs which range in width from a few feet to more than one mile. The Myakka River channel is the only one that is well defined and naturally entrenched throughout its course. Some of the coastal areas, including most of the keys, are just above sea level and have no recognizable stream channels.

Many sloughs and swampy areas have been drained by ditches and canals. The agricultural areas in the upper Big Slough, Phillippi Creek, and Cow Pen Slough basins, and the recently developed residential areas, such as Port Charlotte, have undergone extensive drainage changes.

Below an altitude of about $60 \mathrm{ft}(18 \mathrm{~m})$, hundreds of shallow depressions dot the landscape. Few of these depressions are the sites of perennial ponds or 1akes, but all, unless drained by canals, hold water during wet weather.

The Upper and Lower Myakka Lakes are the largest lakes in the area and have a combined water surface of about 1,380 acres $\left(558 \mathrm{ha}^{2}\right.$ ) at lake levels of 13.6 and $9.9 \mathrm{ft}(4.1$ and $3.0 \mathrm{~m})$ above $\mathrm{ms}$ respectively. The Tatum Sawgrass, a 4,300-acre (1740 ha ${ }^{2}$ ) marsh several miles northeast of Upper Myakka Lake, is several feet above the normal lake level (15-20 ft or 5 - $6 \mathrm{~m}$ above msl). This marsh is flooded only when rainfall is exceptiona11y heavy. 


\section{HYDROLOGY}

The source of all fresh water in the Myakka River basin area is rain falling either on the immediate area or on adjacent areas. Most of the rain that falls on the area evaporates. The rest begins to move toward the sea either over land or beneath the ground surface. The water that remains on the surface may be stored temporarily in lakes, ponds, or sloughs, or may flow in streams toward the sea. The water that filters into the ground and reaches the zone of saturation becomes ground water. Rain falling through the atmosphere picks up small quantities of dust particles, atmospheric gases, exhaust gases, and wind-blow salts which affect the water quality.

When rain reaches the earth, it begins to dissolve or pick up in suspension some of the materials contacted. The extent of solvent action depends largely upon the type of mineral contacted, its susceptibility to chemical and physical attack, contact time, and the chemical composition of the water itself. Surface waters in the Myakka River basin area generally contain only small amounts of dissolved solids. They are often highly colored from contact with leaves and other decaying vegetation in swampy areas and stream channe1s. Ground water on the other hand, is usually low in color, but contains an appreciable amount of salts dissolved from earth materials. 


\section{$\underline{\text { Rainfall and Evapotranspiration }}$}

The unweighted average mean annual rainfall for 33 years at

6 stations in and near the Myakka River basin area is 54.3 in (1380 mm) (fig. 3). Rarely is annual rainfall less than 40 in $(1,020 \mathrm{~mm})$ or more than 70 in $(1,790 \mathrm{~mm})$.

Rainfall shows a marked seasonal distribution, about 60 percent of the annual rainfall occurs in June through September (fig. 3). Most of the summer rainfall is associated with convective thunderstorms that are usually localized, of short duration, and produce high-intensity rainfalls. Tropical depressions and hurricanes may produce heavy rainfall lasting several days during the summer and fall. Hurricane records (U. S. Army, Corps of Engineers, 1961, p. 18) indicate that on the average there is about a 20 percent chance that a hurricane will pass within $50 \mathrm{mi}(80 \mathrm{~km})$ of Sarasota each year.

The dry season is from October to May. Often, in the late spring, no measurable rainfall will occur for 60 days or more. The dry season is the irrigation season for truck crops and citrus and also the period of peak population in this area, Therefore, October to May is the time of high water use and water consumption. 

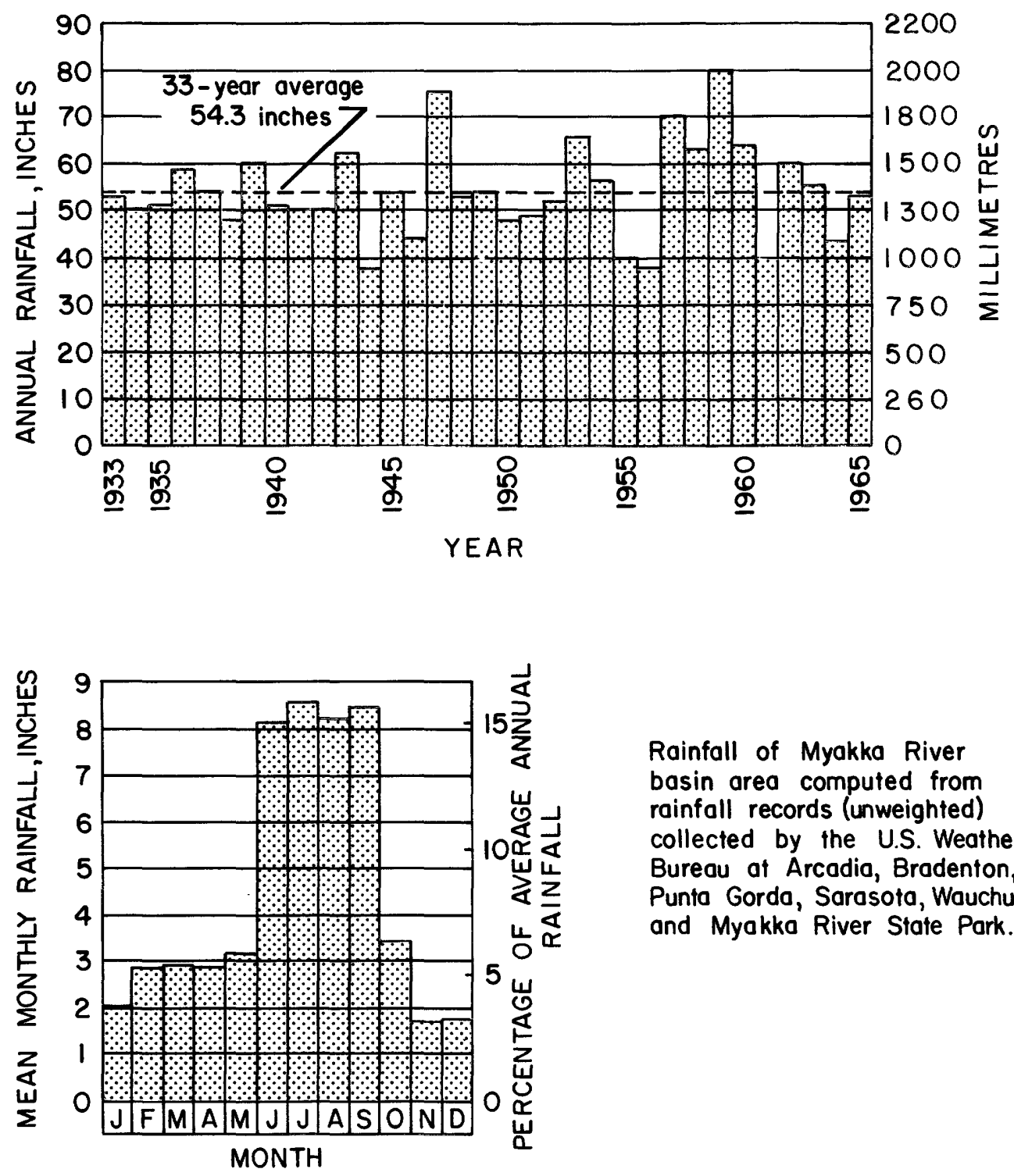

Rainfall of Myakka River basin area computed from rainfall records (unweighted) collected by the U.S. Weather Bureau at Arcadia, Bradenton, Punta Gorda, Sarasota, Wauchula, and Myakka River State Park.

FIGURE 3,--ANNUAL AND MONTHLY RAINFALL IN THE MYAKKA RIVER BASIN AREA, 
A wide range of rainfall conditions occurred during the investigation. The storm of September 20-21, 1962, which occurred before most project stream-gaging stations were in operation, produced a 2-day rainfall of such magnitude as may be expected only once every 20 to 60 years (Miller, 1944). Widespread flooding resulted from this heavy rainfall. On the other hand, the areal rainfall for December 1964 to May 1965 was 29 percent of the mean, resulting in a mild drought. The amount of water lost to evaporation and transpiration in humid areas, such as the Myakka River basin area, is largely a function of air temperature. Data collected by the National Weather Service indicate that the mean annual air temperature in the Myakka River basin area is about $73.2^{\circ} \mathrm{F}\left(22.9^{\circ} \mathrm{C}\right)$. The annual means at the various temperature recording stations in the area are al1 within $1.2^{\circ} \mathrm{F}(0.7 \mathrm{C})$ of the areal mean. Mean daily temperatures range from $84^{\circ} \mathrm{F}\left(29^{\circ} \mathrm{C}\right)$ in summer to $61^{\circ} \mathrm{F}\left(16^{\circ} \mathrm{C}\right)$ in winter. Temperatures as high as $104^{\circ}\left(40^{\circ} \mathrm{C}\right)$ and as 1 ow as $19^{\circ} \mathrm{F}\left(-7.2^{\circ} \mathrm{C}\right)$ have been reported. Temperatures below $32^{\circ} \mathrm{F}\left(0^{\circ} \mathrm{C}\right)$ may be expected about 2 to 4 times each winter; the frequency depends upon the location within the area. Along the coast, temperatures are slightly higher in the winters and lower in the summers than they are in the interior. 
The moderately high temperatures result in a large amount of evapotranspiration. Average annual evapotranspiration is estimated to be $35-40$ in $\left(89-102^{\circ} \mathrm{mm}\right)$, based on the difference between rainfal1 (about 54 in or $1,370 \mathrm{~mm}$ ) and runoff (about 14 in or $360 \mathrm{~mm}$ ) plus ground-water :recharge (about 1 in or $25 \mathrm{~mm}$ ). Average annual lake evaporation is estimated to be 52 in $(1,320 \mathrm{~mm}$ ) (Kohler and others, 1959, p1. 2), and evapotranspiration losses from the numerous predominately wet-weather vegetation-filled ponds in the area probably exceeds 60 in $(2,800 \mathrm{~mm})$ a year. 


\section{Ground Water}

Geologic and Hydrogeologic Units

In the Myakka River basin area, ground water occurs both under artesian and nonartesian (water-table) conditions. An aquifer is under artesian conditions when the water is confined; that is, when water levels in wells that tap the aquifer stand above the top of the aquifer. The water in the artesian aquifers is confined above and below by relatively impermeable beds. Nonartesian, or water-table, conditions occur where the upper surface of the zone of saturation, the water table, is unconfined, and is at atmospheric pressure. The water levels in wells tapping the water-table aquifer are, in genera1, at the same height as the water table.

The Myakka River basin area is underlain by deposits of clastic rocks such as sand, clay, marl, and grave1, of late Tertiary and Quaternary age. These deposits are, in turn, underlain by limestone and dolomite (Table 1). Water in the clastic deposits is contained in the spaces between the constituent grains, whereas much of the water in the limestone and dolomite occurs in fractures and solution cavities. These fractures and solution cavities in limestone and dolomite are best developed in zones that are at or near the contacts between the formations. Each of these zones is norma11y not more than $40 \mathrm{ft}(12 \mathrm{~m})$ thick, and they may overlap a formation boundary and encompass parts of two geologic units. In all, five such zones are recognized in the Myakka River basin area. Their relation to the geologic units is summarized in table 2. The lowermost of these five zones, numbers 3 through 5, together with their confining beds, constitute the Floridan aquifer to the extent that it can be identified in this area. 
Table 1.--Geologic units penetrated by water wells in the Myakka River basin area.

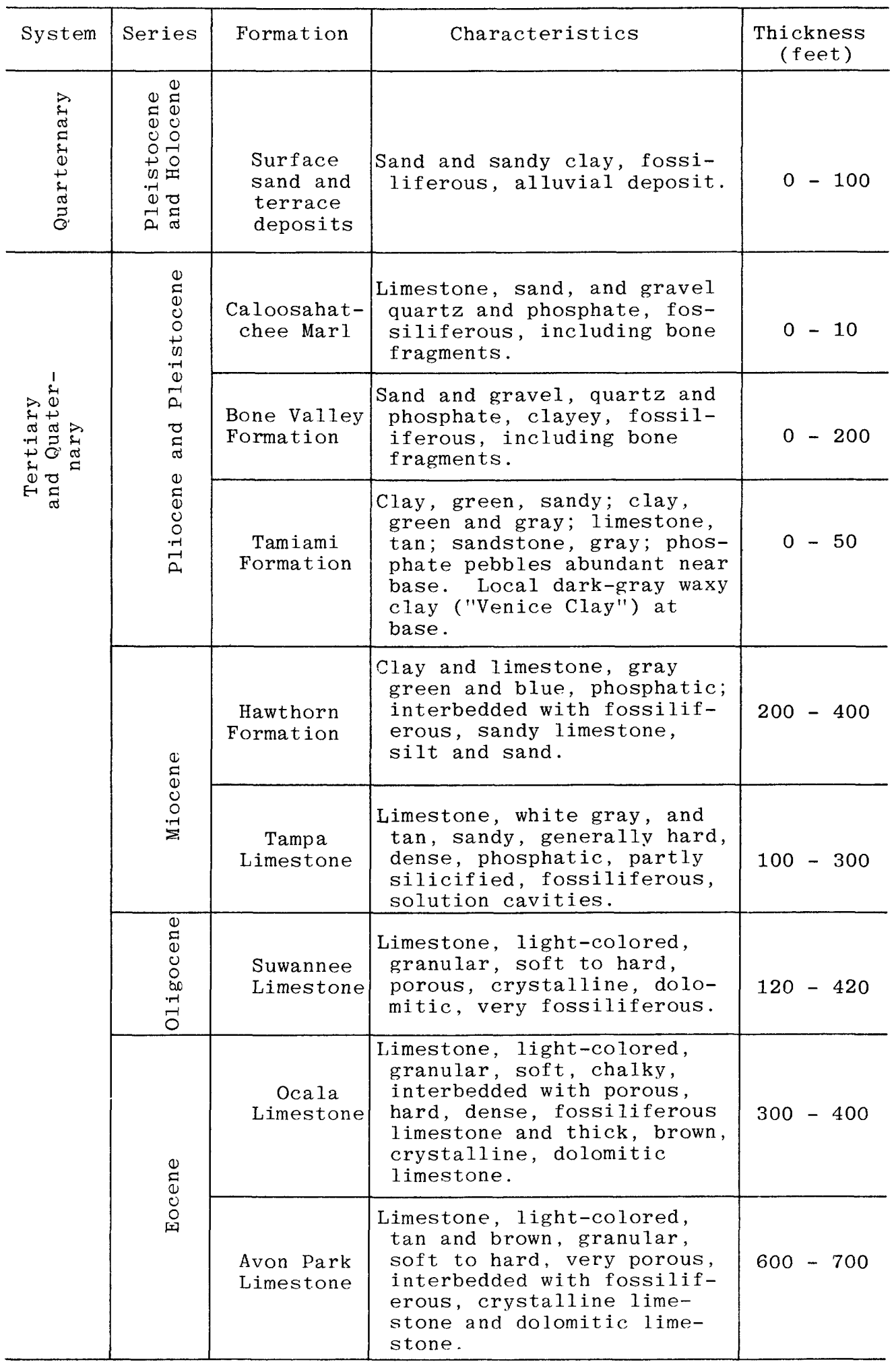


Table 2.--Zonal subdivision of the artesian aquifer system underlying the Myakka River basin area.

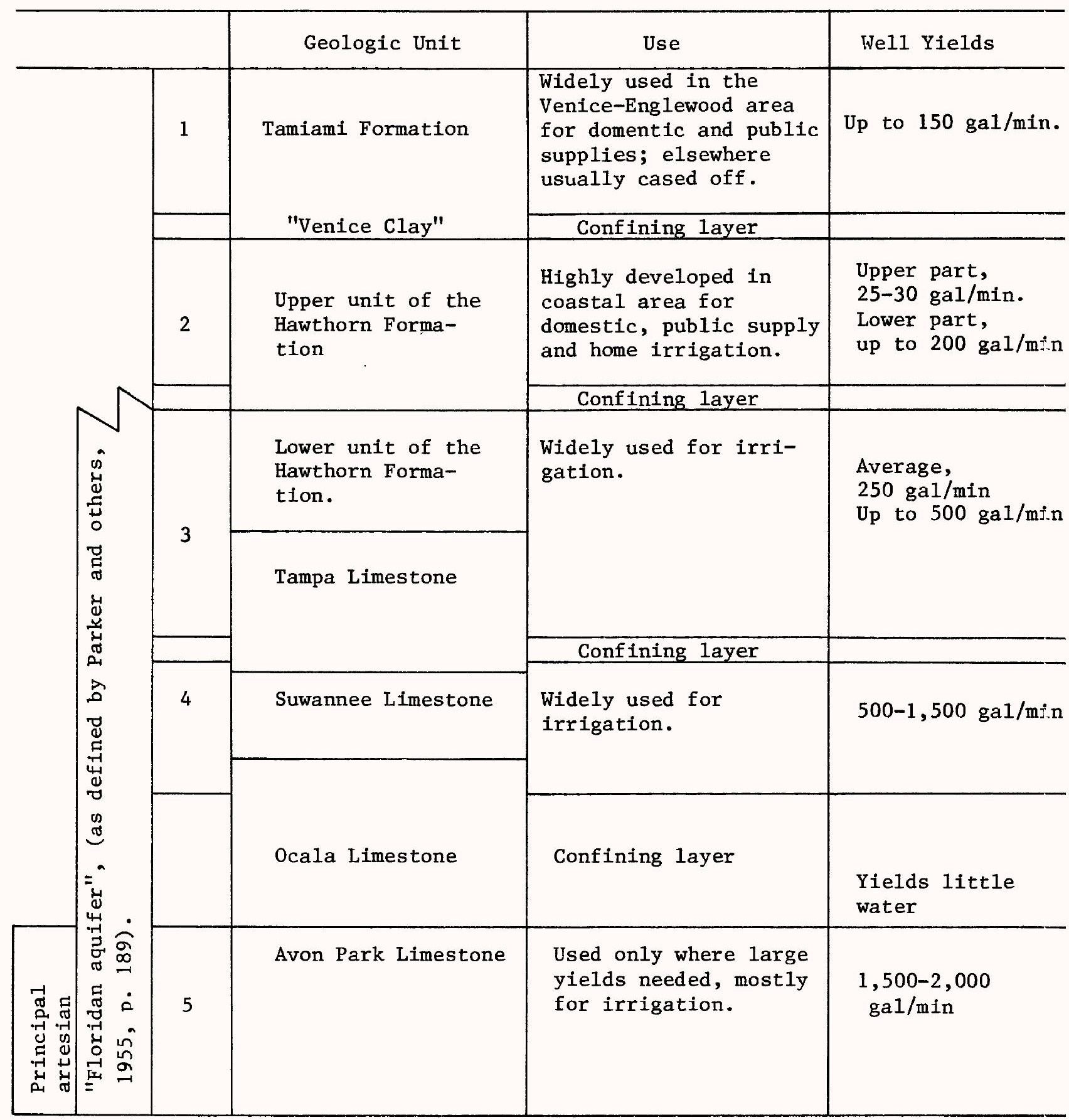


The depth at which any particular rock unit and corresponding waterbearing zone is encountered varies widely over the area because of variations in the thickness and dip of the units. These variations are illusted on the sections shown on figures 4 and 5 . The location of the sections is shown on figure 6. The wells for which data are included in this report have been numbered serially. The U.S. Geological Survey Site Identification Number for each of these we11s is 1isted in a table at the end of the report. The formation contacts were determined from electric and gamma-ray logs of wells and verified by examination of cuttings from key wells. The sections show that the formations generally dip to the southwest; but local variations in dip occur. The variations may be due in part to faulting, but structural control data are insufficient to determine the presence or position of actual faults.

The deeper units are not shown on the sections because of insufficient data. The Avon Park Formation, the upper part of the deepest water-bearing zone penetrated by wells, ranges from about 1,000 feet (300 $\mathrm{m}$ ) below land surface in the north and east to about 1,500 feet $(460 \mathrm{~m})$ below in the south and west.

\section{Water-Table Aquifer}

The water-table aquifer consists of Quaternary deposits, the Caloosahatchee Marl, and the Bone Valley Formation of Pleistocene and P1iocene age. It underlies the entire basin and consists of layers of sand, shells, mar1, phosphate gravel, and organic material intermixed locally with sandy clay. The aquifer ranges in thickness from a few feet along the coast and on the keys to more than $100 \mathrm{ft}(30 \mathrm{~m})$ in the eastern part 


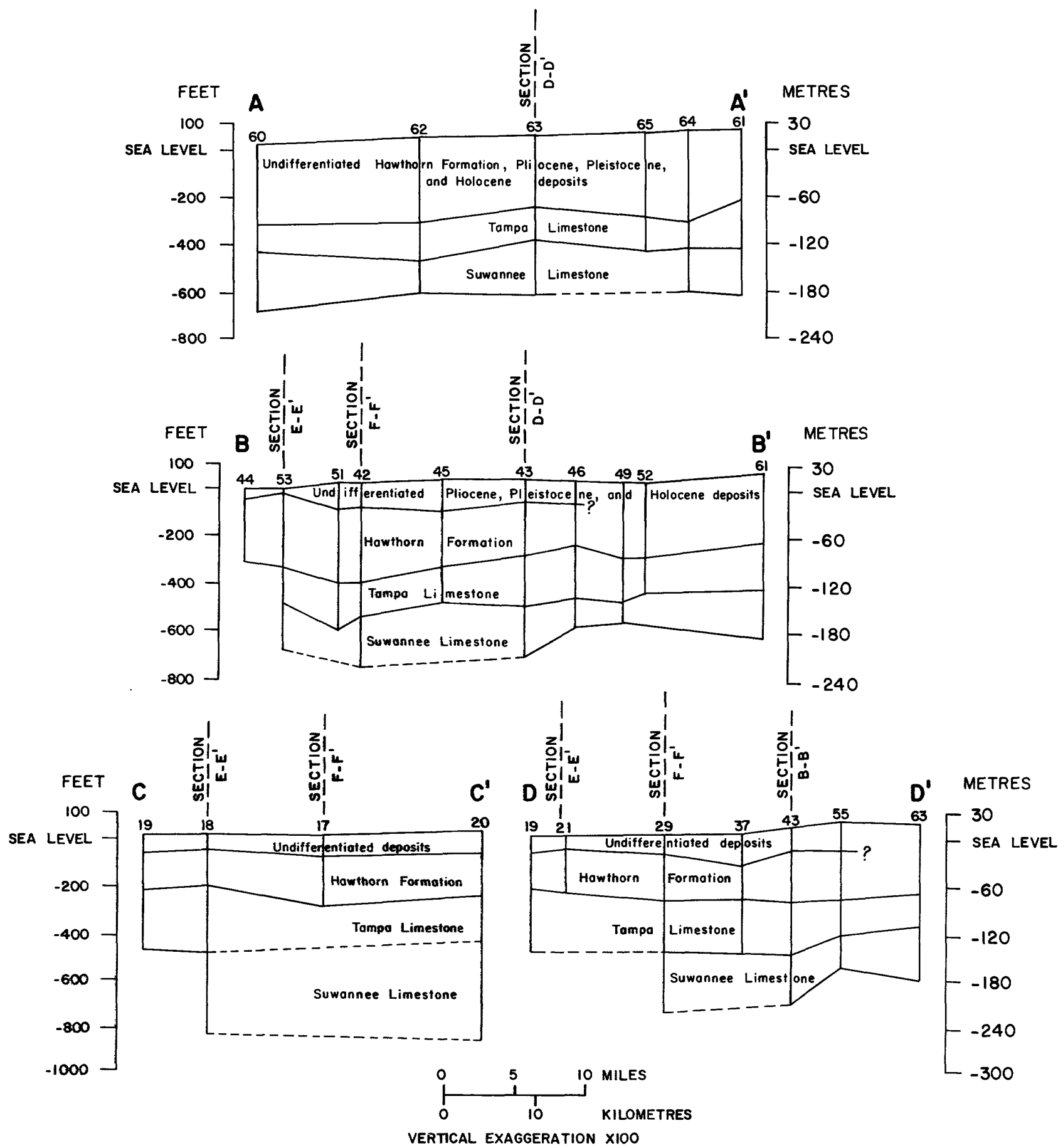

FIGURE 4,-- GENERALIZED SECTIONS A-A', B-B', C-C', AND D-D' SHOWING LITHOLOGIC UNITS OF OLIGOCENE AGE AND YOUNGER, UNDERLYING THE MYAKKA RIVER BASIN AREA. (LOCATION OF SECTIONS SHOWN ON FIG, 6.) 

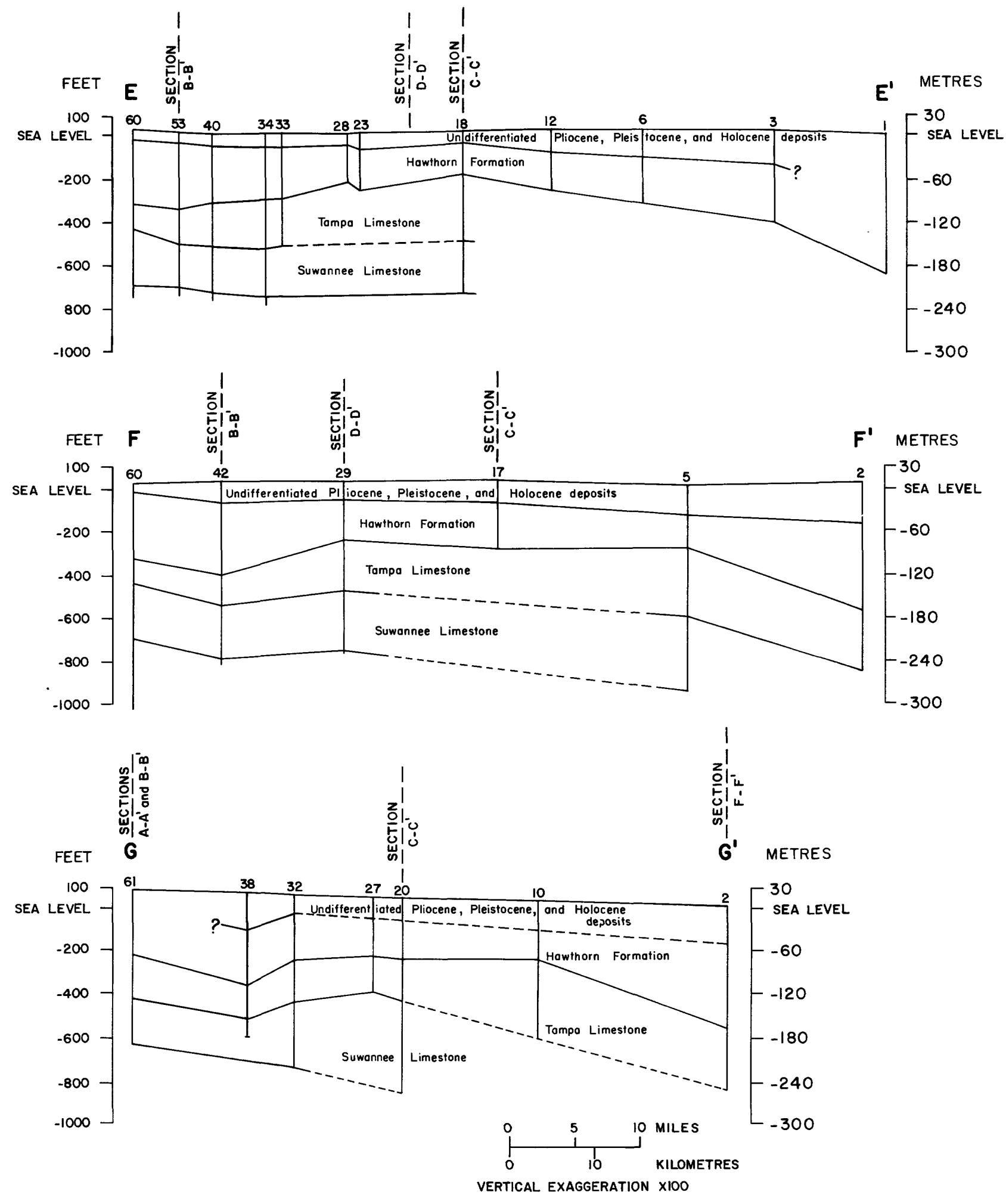

FIGURE 5,--GENERALIZED SECTIONS E-E', F-F', AND G-G' SHOWING LITHOLOGIC UNITS OF OLIGOCENE AGE AND YOUNGER, UNDERLYING THE MYAKKA RIVER BASIN AREA. (LOCATION OF SECTIONS SHOWN ON FIG, 6.) 


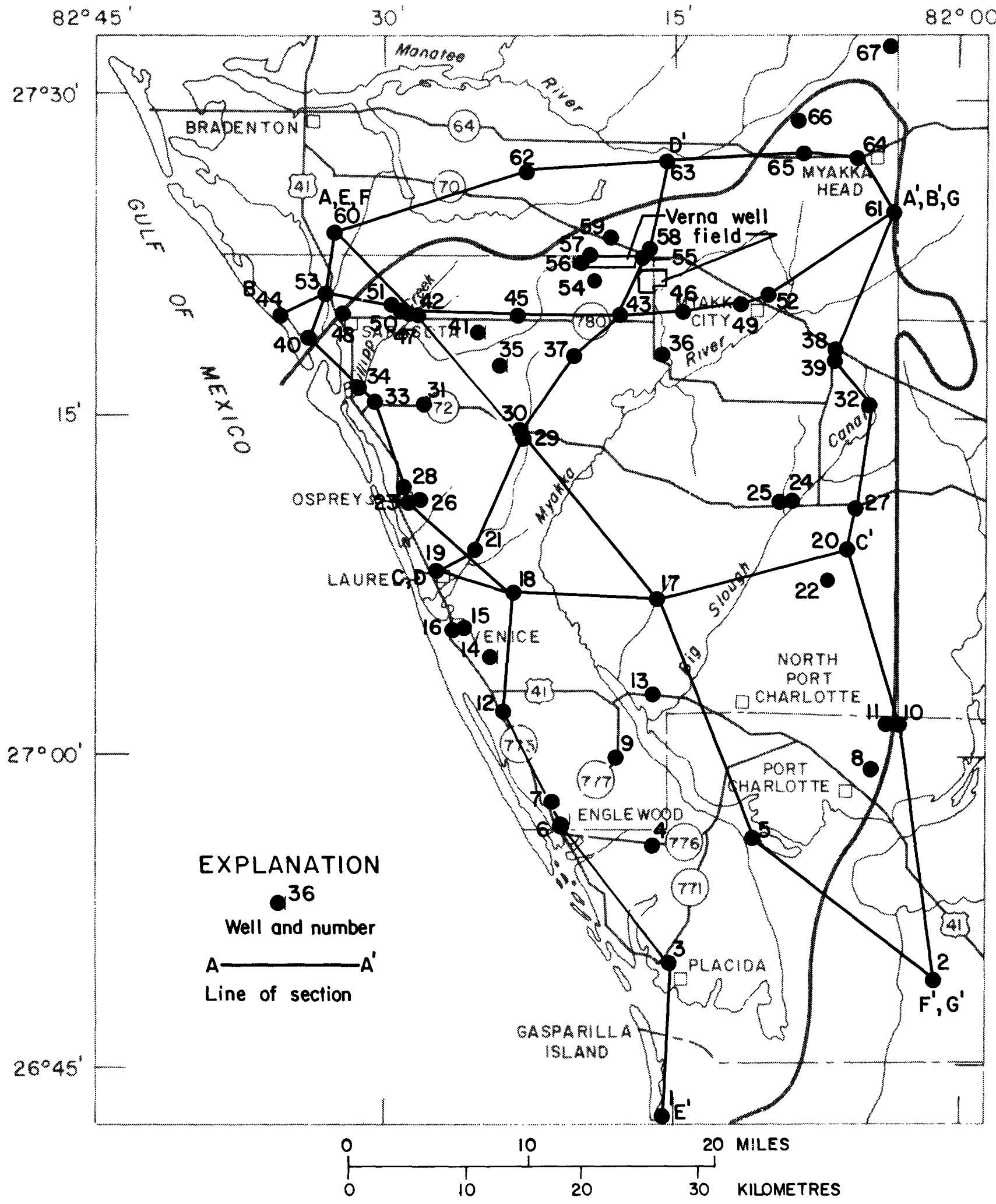

FIGURE 6,--LOCATIONS OF WELLS REFERRED TO IN THIS REPORT AND LINES OF SECTIONS 
of the area, and has a wide range of productivity related to the type of the materials of which it is composed.

The water-table aquifer was virtually undeveloped in 1966 yet has the greatest potential as a dependable water supply because of the east with which it can be recharged by precipitation. It also has the greatest potential for contamination from surface sources. Most of the wells that tap the water-table aquifer are small-diameter drive-point wells, particularly in the interior of the basin. Limited use is made of the water-table aquifer on some of the keys where several wells often are installed for a single supply. By the use of several widely spaced lowyield wells instead of one well with a high yield, drawdown in an individual well can be reduced; this is an important consideration in the control of saltwater intrusion into the aquifer. Many smal1-diameter drive-point wells are used for watering livestock. A few irrigation we11s, 3 to 4 in ( 76 to $100 \mathrm{~mm}$ ) in diameter are 
completed with open end. Some of these wells yield as much as $50 \mathrm{gal} / \mathrm{min}(3 \mathrm{l} / \mathrm{s})$. Yields of as much as $100 \mathrm{gal} / \mathrm{min}(6 \mathrm{l} / \mathrm{s}) \mathrm{could}$ be obtained from screened or gravel pack wells.

The water-table aquifer is recharged locally under both natural and artificial conditions. Natural recharge occurs as direct infiltration of rainfall and as upward leakage from the underlying artesian aquifers where the altitude of the potentiometric surface of the artesian aquifer is higher than that of the water-table aquifer. Recharge also occurs as influent seepage from streams that are at high stage. Artificial recharge occurs from streams ponded behind control structures, infiltration of irrigation water, discharge from septic tanks and the infiltration of water from uncapped flowing we11s.

Discharge from the water-table aquifer occurs under both natural and man-induced conditions. Natural discharge occurs by evapotranspiration; seepage into ponds, canals, and streams; and downward leakage in the underlying aquifers. Downward leakage can take place only where the water table is higher than the potentiometric surface of the underlying artesian aquifers. Man-induced discharge results from pumping from wells and draining of water into deep ditches constructed in the agricultural areas to control the depth to the water table. 
The depth to the water table in the Myakka River basin area ranges from less than $1 \mathrm{ft}(0.3 \mathrm{~m})$ to more than $15 \mathrm{ft}(4 \mathrm{~m})$ below land surface. In most places the depth to the water table is less than $8 \mathrm{ft}(2.5 \mathrm{~m})$ due to the low topographic relief of the basin. In the extreme northern and northeastern parts of the basin, adjacent to we11-defined drainage channels, the water table may be more than $15 \mathrm{ft}$ ( $4 \mathrm{~m}$ ) below land surface, particularly during exceptionally dry periods. The water table lies fairly close to land surface on the keys. Water levels in the wells that tap the water-table aquifer generally fluctuate seasonally in response to variations in recharge and discharge. That is, the water levels decline to a low during the dry spring months and recover generally during the wet summer months to a seasonal high. Water-level fluctuations shown on figure 7 are characteristic of the water-table aquifer. 


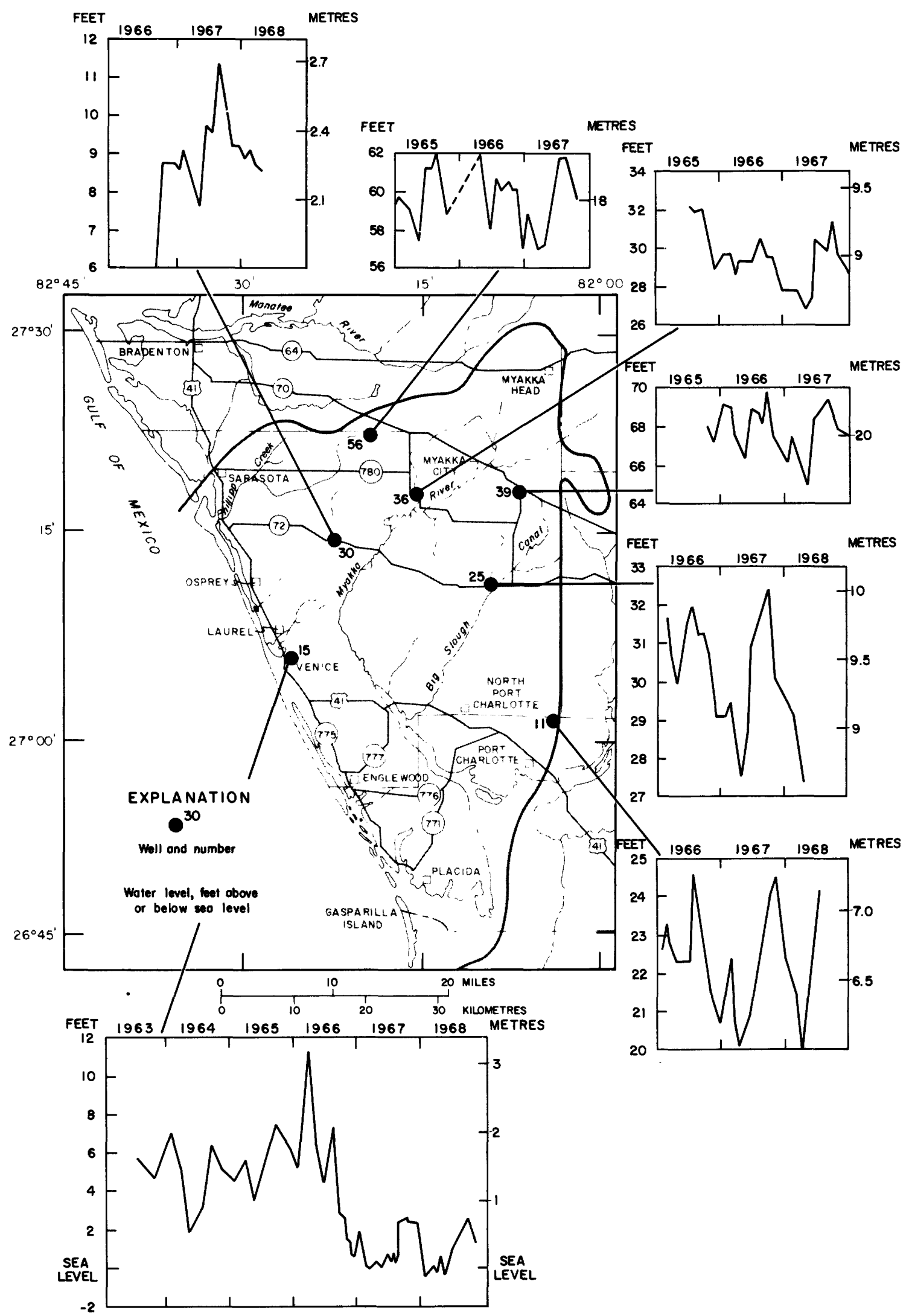

FIGURE 7,--HYDROGRAPHS OF SELECTED OBSERVATION WELLS TAPPING THE WATER-TABLE AQUIFER. 
Water obtained from the aquifer is generally of acceptable quality except where saltwater intrusion has taken place near the coast and in the peninsula south and west of the Myakka River estuary (fig. 8). The water in the interior part of the area of investigation generally meets the criteria of the EPA (Environmental Protection Agency) for public water supply (National Academy of Sciences and National Academy of Engineering, 1973). Some constituents in raw water in the peninsula and coastal areas occur in concentrations that exceed these criterla. The principal problem constituents and the EPA criteria are listed below:

\begin{tabular}{c|c} 
Water-quality criteria for selected constituents \\
\hline Constituent & $\begin{array}{c}\text { Recommended } \\
\text { 1imit } \\
\text { (mg/1) }\end{array}$ \\
\hline Sulfate & 250 \\
Chloride & 250 \\
Fluoride & 1.6 \\
Iron & .3 \\
Color & a75 \\
\hline
\end{tabular}

a Platinum-cobalt units 


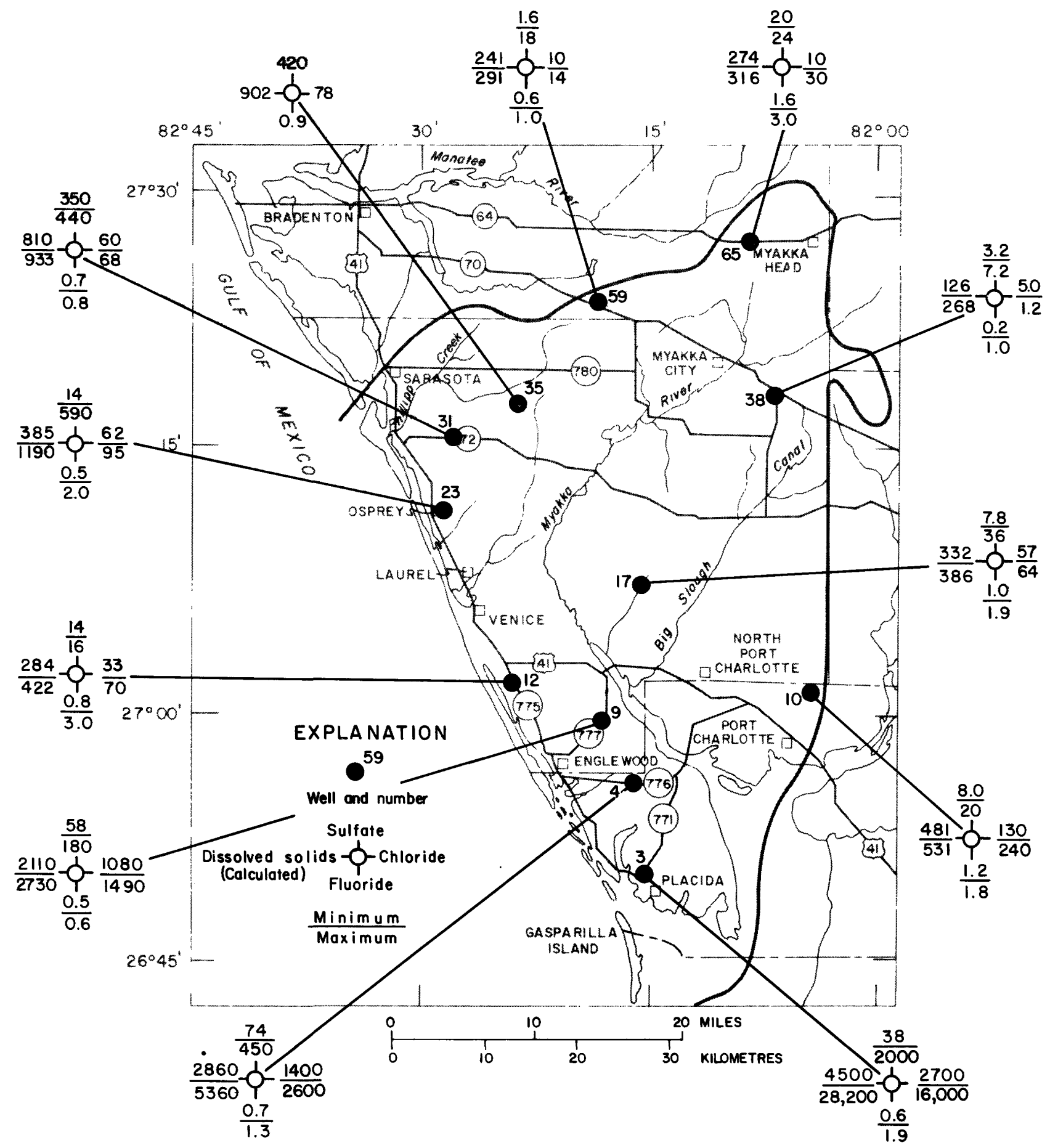

FIGURE 8,--CHEMICAL QUALITY OF WATER FROM WELLS TAPPING THE WATER-TABLE AQUIFER 
Most water in the water-table aquifer underlying the peninsula and along the coast is highly mineralized (fig. 8). Chemical characteristics of the water from well 3 near Placida indicate intrusion of saltwater. In well 9, which is $5 \mathrm{mi}(8 \mathrm{~km})$ inland from the Gulf, chloride and dissolved-solids concentrations of the water are also above the recommended limits for drinking water. This we11, however, may be contaminated by leakage from an artesian aquifer. In many places along the coast, the dissolved-solids concentration of water from we11s approaches that of seawater. However, a few wells in shell beds on the Keys yield small quantities (5-10 gal/min or $0.3-0.61 / \mathrm{s}$ ) of potable water. Some wells that tap the shallow shell and sand beds south of Sarasota yield water with about $2 \mathrm{mg} / 1$ of iron.

Wel1 7 at Englewood and well 13 (fig. 6) near U.S. Highway 41 at the Myakka River are pub1ic-supply wells for the Englewood Water District and a private utility, respectively. Except for a color of 100 units, water from wel1 7 is of excellent quality. Water from well 13 contains high concentrations of iron $(1.42 \mathrm{mg} / 1)$, dissolved solids, sodium, and chloride. The high sodium and chloride concentrations indicate saltwater intrusion from the Myakka River estuary or from the stream draining Warm Mineral (Salt) Springs. Well 13 is being pumped at a rate of $66 \mathrm{gal} / \mathrm{min}(4.21 / \mathrm{s})$. 
In the Myakka River basin area, the artesian aquifer system is composed of five separate and distinct producing zones. These zones have been identified in the rock sequence between the base of the water-table aquifer and the base of the Avon Park Limestone (table 2). The identification of these zones is based on their stratigraphic position, 1ithology, productivity, water level, and the chemical quality of the water produced from them. Test-drilling procedures developed for this study permit identification of the producing zones (Sutcliffe and Joyner, 1968); the zones were further defined by test drilling in Sarasota's well field near Verna and by the use of packer tests as described by Sutcliffe and Joyner (1966). Zones 3 through 5 are in that part of the limestonedolomite sequence that is occupied by the Floridan aquifer elsewhere in the State, except that, in general, the base of the Floridan aquifer, as defined by Parker and others (1955), includes parts or a11 of the Avon Park and Lake City Limestones. In the Myakka area, no wells have penetrated the Lake City Limestone. The upper part of the Hawthorn Formation where here includes zone-2 (table 2) generally is not considered a part of the Floridan aquifer at other locations in the State.

The separate zones are difficult to distinguish using water-level, productivity and water-quality information from production wells, because most of these wells are cased only to the first hard-rock stratum, usualiy to depths less than $200 \mathrm{ft}(61 \mathrm{~m})$. Thereafter, the wells are usually open hole through more than one zone, and the water pumped from the wells 
comes from all zones penetrated by the open hole. As a result, information obtained as the well is being drilled and changes observed as the well enters each zone better define the characteristics of each zone and the differences between zones than information obtained after completion of the well. Every effort was made to collect data from wells as they were being drilled and these data, along with those from the previously mentioned testing programs, were used to define the following artesian zones.

Artesian Zone-1

Zone-1 consists of the semiconsolidated she11, clay, and limestone beds of the Tamiami Formation which lie between the base of the Bone Valley Formation and the so-called "Venice Clay" of local usage. The "Venice Clay" is in the lower part of the Tamiami Formation. The zone underlies the coastal area from Sarasota to Placida and extends inland 10 to $12 \mathrm{mi}$ (16 to $19 \mathrm{~km})$. This zone is widely used in the Venice area for domestic and public supplies. Wells 2 to 3 in (50 to $75 \mathrm{~mm}$ ) in diameter that are equipped with centrifugal pumps produce as much as $30 \mathrm{gal} / \mathrm{min}(1.9 \mathrm{1} / \mathrm{s})$ from the zone. The water level of zone-1 is generally less than $10 \mathrm{ft}$ ( $3 \mathrm{~m}$ ) below land surface except on the highest ridges.

Water Quality.--Water of acceptable quality for domestic and public supply is obtained from wells that tap zone-1 except in the peninsula south and west of the Myakka River estuary. The following table 1ists some constituents and their concentrations in water from well 42 near Phillippi Creek and well 3 at Placida, on the peninsula. The locations of both wells are shown on figure 6. The table shows the contrast in chemical quality. 
Constituent We11 $42 \quad$ We11 3

(Concentrations in milligrams per 1itre)

\begin{tabular}{lrc}
\hline Dissolved solids & 380 & $\mathrm{a} 27,000$ \\
Sulfate & 4 & 1,900 \\
Chloride & 35 & 15,000 \\
Fluoride & .5 & $0^{.6}$ \\
Hardness & $290^{.5}$ & 5,000 \\
\hline
\end{tabular}

a estimated

High concentration of several constituents in the water from wel1 3 makes it unsuitable for most purposes. Water from we11 42 is chemically similar to water from other test wells at Osprey and in the south-central part of the study area that tap zone-1. Water samples from all the we11s there meet the EPA criteria for public water supplies. In a sample from wel1 12 (fig. 6) dissolved solids concentration was $580 \mathrm{mg} / 1$. High color in water from well $12--45$ units--is probably caused by the water moving downward through the overlying shell beds to the recharge zone. These she11 beds are rich in organic material.

Some of the wells supplying Englewood, Venice and two subdivisions in the Venice area produce water from zone-1. Except for high color, this water is of good quality. Analyses of water from wells 6 and 14, tapping zone-1 in the Englewood and Venice areas are 1isted in table 3. 
TABLE 3.--Analyses of water from wells 6 and 14, tapping Zone-1 in the Englewood and Venice area. (Analyses by U.S. Geological Survey; in milligrams per litre except specific conductance, $\mathrm{pH}$, and color.)

We11

6

14

Date of collection

January 7, 1965

January 8, 1965

Depth of wel1 (feet)

82.5

64

Silica $\left(\mathrm{SiO}_{2}\right)$

16

22

Iron $\left(\mathrm{F}_{\mathrm{e}}\right)$

.06

.11

Calcium (Ca)

96

72

Magnesium ( $\mathrm{Mg}$ )

6.2

55

Sodium ( $\mathrm{Na})$

25

37

Potassium (K)

1.6

1.4

Bicarbonate $\left(\mathrm{HCO}_{3}\right)$

Sulfate $\left(\mathrm{SO}_{4}\right)$

.0

.0

Chloride (c1)

50

130

Fluoride (F)

.0

.0

Nitrate $\left(\mathrm{NO}_{3}\right)$

.0

.0

Phosphate $\left(\mathrm{PO}_{4}\right)$

2.3

.0

Dissolved solids

Calculated

Residue

Hardness

Specific conductance

(micromhos $/ \mathrm{cm}$ at $25^{\circ} \mathrm{C}$ )

$\mathrm{pH}$

Color
340

557

408

265

405

561

1,040

7.5

7.5

40

40 
Artesian Zone-2

Zone-2 is the most highly developed artesian zone in the populous coastal area. It furnishes most of the water used for domestic, home irrigation, and public water supplies. Zone-2 consists of the permeable beds in the upper unit of the Hawthorn Formation. These beds underlie the area at depths ranging from 65 to $250 \mathrm{ft}(20$ to $76 \mathrm{~m})$ below land surface. The zone thickens toward the southeast. The zone is overlain by the so-called "Venice Clay" of the lower part of the Tamiami formation wherever the clay is present. Elsewhere the zone includes the lower part of the Tamiami Formation and is overlain by deposits which have low permeability.

Along the coast, zone- 2 is tapped by 22 public water-supply wells. The city of Sarasota derives about two-thirds of its average daily pumpage of $3.86 \mathrm{Mgal} / \mathrm{d}\left(15,000 \mathrm{~m}^{3} / \mathrm{d}\right)$ from the zone. The zone is also the source of 40 percent $(0.2 \mathrm{Mgal} / \mathrm{d})\left(800 \mathrm{~m}^{3} / \mathrm{d}\right)$ of city of Venice's average daily pumpage. Because other public supply systems use wells that produce from zones 1 and 2 , the quantity of water being produced from zone 2 alone is difficult to estimate. Sma11-diameter wells (2 in or $50 \mathrm{~mm}$ ), that tap only the upper part of the zone may produce 25 to $30 \mathrm{gal} / \mathrm{min}(1.6$ to $1.9 \mathrm{l} / \mathrm{s})$. Higher yields are generally obtained from wells pentrating more of the zone. Larger wells (up to 6 in or $160 \mathrm{~mm}$ in diameter) that fully penetrate the zone produce as much as $200 \mathrm{gal} / \mathrm{min}(13 \mathrm{l} / \mathrm{s})$ with about $20 \mathrm{ft}$ ( $6 \mathrm{~m})$ of drawdown. 
The water level in zone-2 fluctuates in response to withdrawals. In areas where withdrawal is concentrated, such as in the housing subdivisions near the coast, water levels may decline $20 \mathrm{ft}(6 \mathrm{~m})$ or more during extended dry periods. This decline has caused many domestic users to be without water when the water level in their wells drop below the lift capacity of the shallow-well pumps. Even in rural areas, water levels in zone-2 may fluctuate substantially (fig. 9) in response to pumping of irrigation wells.

The level in well 35, near a housing subdivision, declined about 24 ft $(7 \mathrm{~m})$ from early fall of 1966 to spring of 1967 . The level in well 24 , in a rural area, declined about $5 \mathrm{ft}(1.5 \mathrm{~m})$ during the same period. Water-Quality--Water-quality deteriorates with increasing depth within zone-2. The maximum and minimum concentrations of selected chemical constituents in water sampled collected during drilling test wells are shown on figure 10. In some areas, fluoride, chloride, and sulfate concentrations exceed the recommended standards for public supply (table 2b). So, these constituents are usually the controlling factors in determining the potability of the water in this zone. Chloride concentrations are excessive only in the peninsula southwest of the Myakka River estuary

Fluoride in concentrations greater than $1.6 \mathrm{mg} / 1$ occur throughout zone2 in the extreme part of the study area, and in the lower part of this zone in the southwestern part of the area. In water samples collected from zone-2 from test wel1 65, near Myakka Head, fluoride was at least 


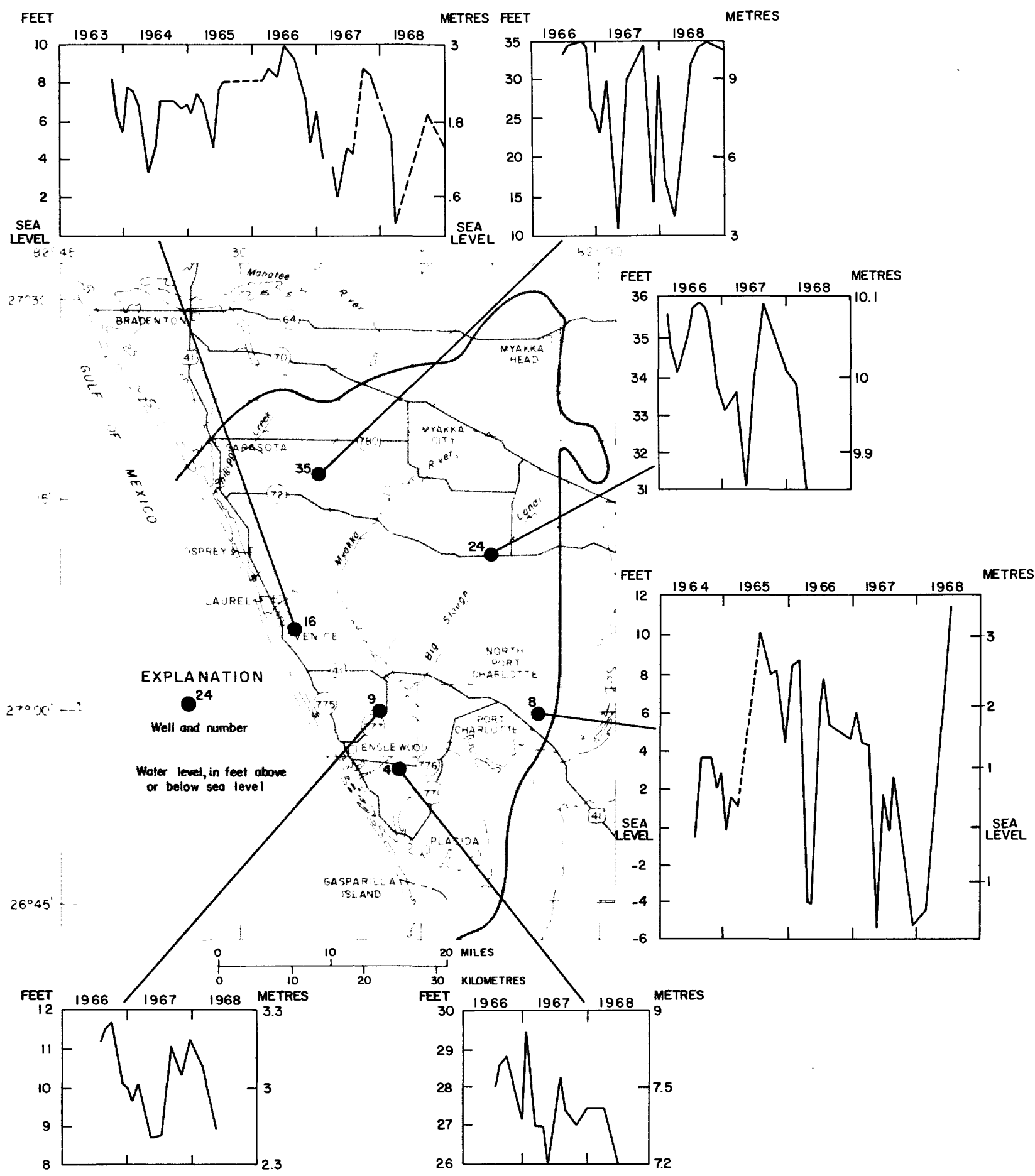

FIGURE 9,--HYDROGRAPHS OF SELECTED OBSERVATION WELLS TAPPING ZONE-2 


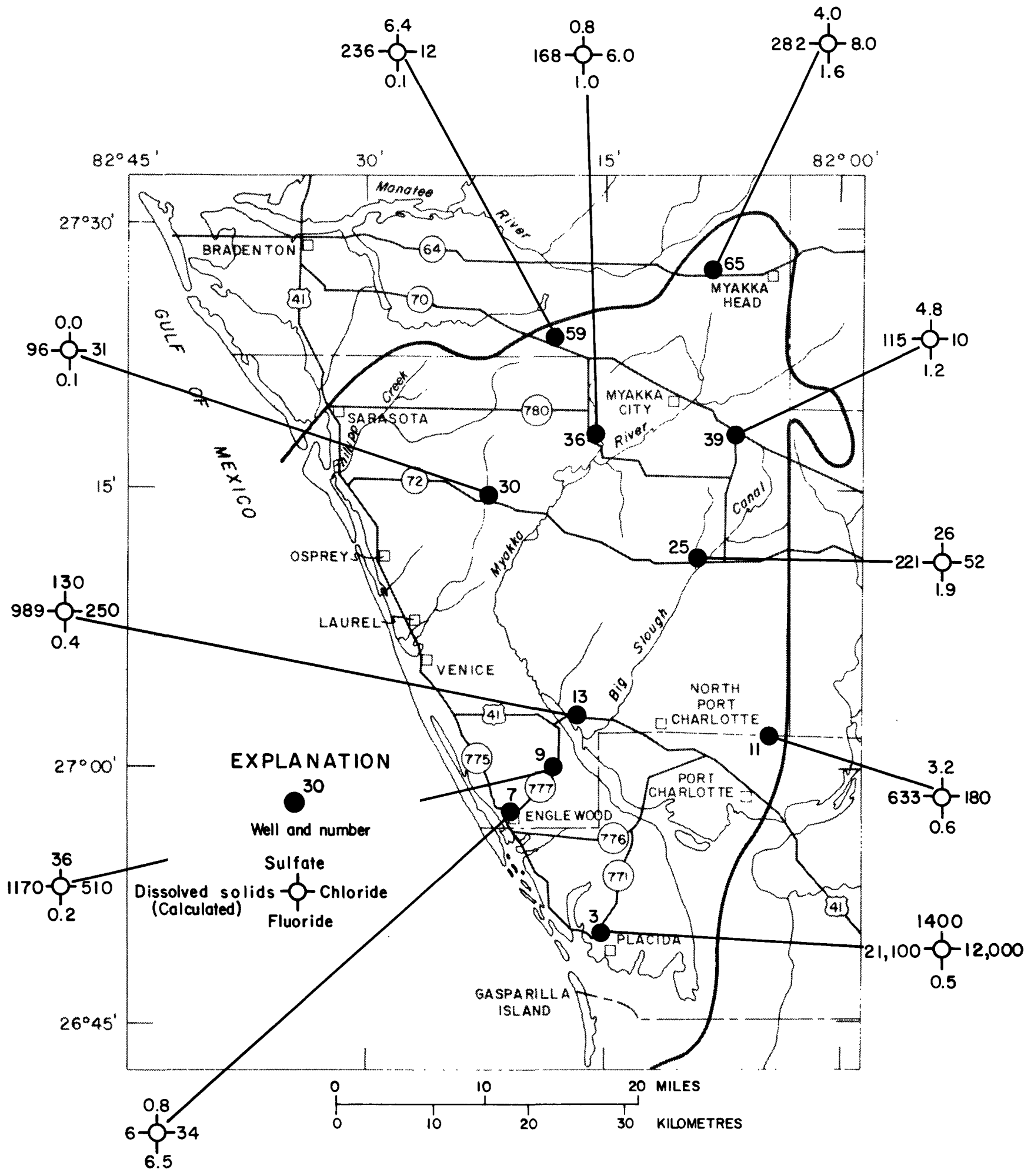

FIGURE 10,--CHEMICAL QUALITY OF WATER FROM WELLS TAPPING ZONE-2 
$1.6 \mathrm{mg} / 1$. High fluoride concentrations in water from wells in the southwestern part part of the area can be avoided by tapping only the shallower parts of the zone. For example, fluoride concentration in water from zone-2 from 37-125 ft (11-38 m) was 1 ess than $1 \mathrm{mg} / 1$ in test well 23 (fig. 6) near 0sprey. Below $125 \mathrm{ft}(38 \mathrm{~m}$ ) the fluoride concentration was $2 \mathrm{mg} / 1$, in we11 23. 
Sulfate concentrations were in excess of $250 \mathrm{mg} / 1$ in a11 water samples collected from test wells 31 and 35 (fig. 6) that tapped zone 2. Wells 3,4 , and 23 (fig.6) also contain water with high concentration of sulfate at some depths. For example, at well 3 the sulfate concentration of water was $2,000 \mathrm{mg} / 1$ at $84-97 \mathrm{ft}(26-30 \mathrm{~m})$, but only $38 \mathrm{mg} / 1$ at $186-212 \mathrm{ft}(57-65 \mathrm{~m})$. Therefore, in these areas high sulfate concentrations can usually be avoided in wells tapping zone-2 by casing out those intervals (84-97 $\mathrm{ft}$ for wel1 3) that yield water with high sulfate.

Chloride concentrations in the water from zone-2 are less than $250 \mathrm{mg} / 1$ in the peninsula southwest of the Myakka River estuary. We11 3 had the highest concentration recorded for the aquifer, $16,0 \mathrm{CO} \mathrm{mg} / 1$. This sample was obtained from within the aquifer interval 84 to $97 \mathrm{ft}(26-30 \mathrm{~m})$ below land surface. The concentration was substantially less but still high $(2,700 \mathrm{mg} / 1)$ in a sample collected from a deeper interval, 136-184 ft (41-56 m), below land surface. Although this chloride concentration greatly exceeds that recommended for public water supplies, it is well with the range for use by most desalinization processes.

Dissolved-solids concentration exceeded $2,000 \mathrm{mg} / 1$ in al1 samples taken from zone 2 in the peninsula southwest of the Myakka River estuary. A sample of water from well 3, collected from zone-2 within the interval $84-97 \mathrm{ft}(26-30 \mathrm{~m})$ contained $28,200 \mathrm{mg} / 1$ of dissolved solids. However, at 186 to $212 \mathrm{ft}$ below land surface, water was found whose dissolved-solids concentration was only 4,500 $\mathrm{mg} / 1$ which is suitable for desalting. Dissolved solids in water from the lower part of zone 2 in well 23 exceeded $1,000 \mathrm{mg} / 1$. 


\section{Artesian zone-3}

Zone-3 includes the permeable rock in the lower part of the Hawthorn Formation and the upper part of the Tampa Limestone (table 2). The zone consists of sand, sandy limestone, clay and hard limestone streaks that contain dark phosphatic pebbles throughout. This aquifer underlies the entire Myakka River basin area. The depth to the top of the aquifer increases from about $250 \mathrm{ft}(76 \mathrm{~m})$ below land surface in the northeast to about $450 \mathrm{ft}(140 \mathrm{~m})$ in the southwest.

Zone-3 is widely used as a source of irrigation water and yields as much as $500 \mathrm{gal} / \mathrm{min}(32 \mathrm{l} / \mathrm{s})$ to individual we1ls. Test wells tapping this unit in the northeastern part of Sarasota County yielded $250 \mathrm{gal} / \mathrm{min}(16 \mathrm{1} / \mathrm{s})$ with $90 \mathrm{ft}(27 \mathrm{~m})$ of drawdown. A few wells that tap both zone-2 and-3 produce 1,500 to $2,000 \mathrm{gal} / \mathrm{min}$ (95 to $126 \mathrm{l} / \mathrm{s}$ ) with $90 \mathrm{ft}(27 \mathrm{~m})$ of drawdown. 
Water Quality.--The fluoride concentration in water from zone-3 in most of the area generally is high. For example, of the eight wells whose locations are shown on figure 11 , al1 yielded water whose maximum fluoride concentrations, on the basis of recurrent sampling, were 1.7 $\mathrm{mg} / 1$ or more. The minimum fluoride concentration was $1.0 \mathrm{mg} / 1$ or 1 ess for four of the eight wells. In genera1, water from zone-3 can be used for drinking by constructing wells that are open to both zones 2 and 3 , thereby diluting zone-3 water with zone- 2 water which is slightly less in fluoride concentration. The city of Sarasota uses water from.zones 2 and 3 near Verna for their public supply. Fluoride concentration of mixed water is $1.5 \mathrm{mg} / 1$; that obtained from zone-3 at Verna is $3.7 \mathrm{mg} / 1$. In general, where the fluoride, sulfate, and chloride concentrations in water from zone-3 meet drinking water standards, it is usable for public supply. Results of test drilling indicate that, in general, these standards are more readily met by water in the upper part of the zone than water from the lower part, particularly in the central segment of the Myakka River basin area. 


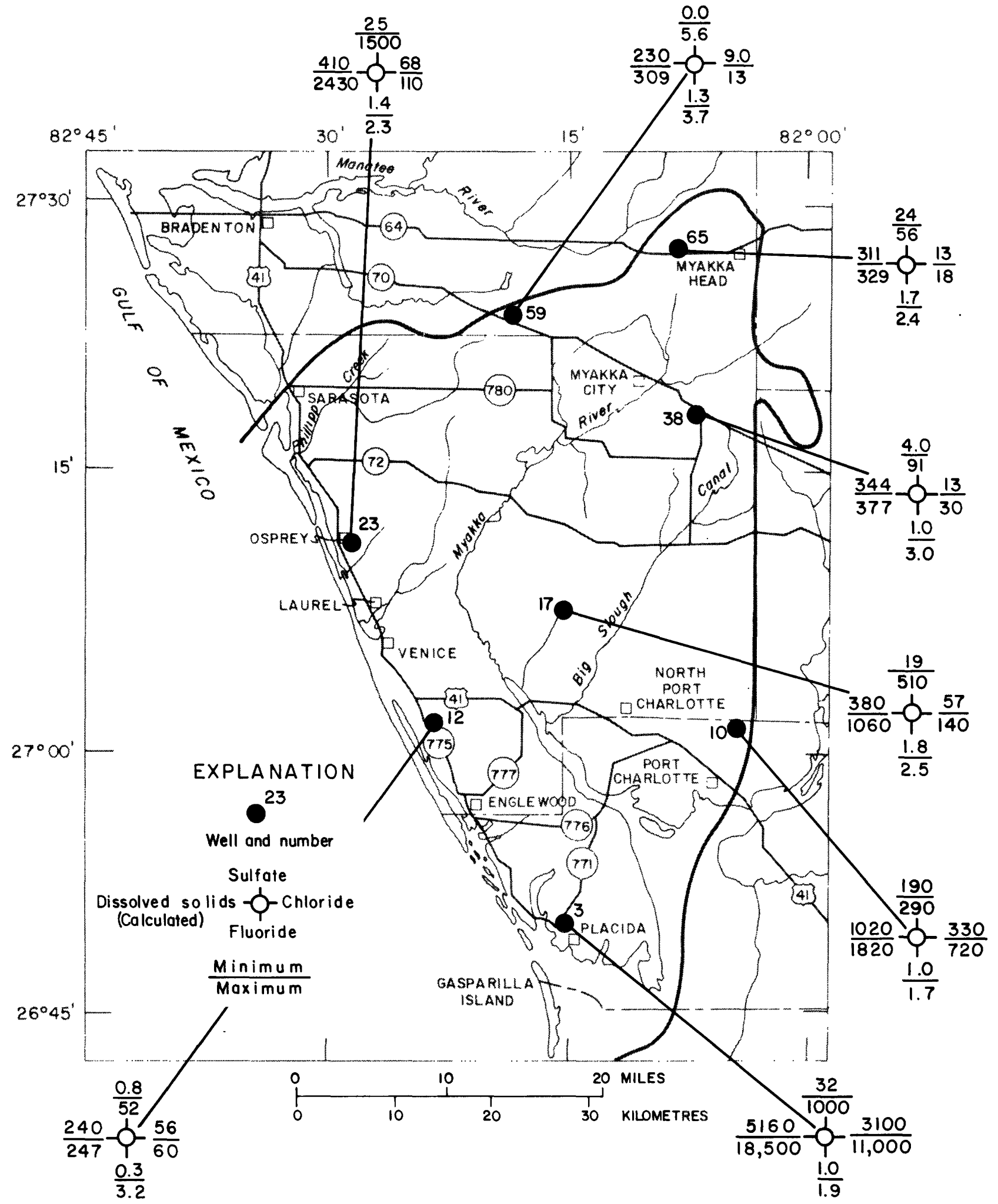

FIGURE 11,--CHEMICAL QUALITY OF WATER FROM WELLS TAPPING ZONE-3. 
Zone -4 underlies all of the Myakka River basin area and consists of the lower part of the Tampa Limestone, all of the Suwannee Limestone and the upper part of the Ocala Limestone. The depth to this zone ranges from about $500 \mathrm{ft}(150 \mathrm{~m})$ in the northeast to about $700 \mathrm{ft}(210 \mathrm{~m})$ in the south and probably to greater depths in the southwest. The zone consists of two segments, an upper and lower, separated by a less permeable layer of limestone and white clay. Caliper logs of wells that penetrate this zone indicate that the upper segment is generally about 50 to $60 \mathrm{ft}$ (15 to $18 \mathrm{~m}$ ) thick and lies within 20 to $40 \mathrm{ft}$ ( 6 to $12 \mathrm{~m}$ ) of the top of the Suwannee Formation and that the lower segment is 30 to $50 \mathrm{ft}$ ( 9 to $15 \mathrm{~m})$ thick. The logs show that the less permeable layer is $30 \mathrm{ft}$ $(9 \mathrm{~m})$ thick. Geophysical logs of wells indicate that in some parts of the area the two segments may be sufficiently interconnected vertically to form a single hydrologic unit.

Zone-4 is one of the most productive of the artesian zones, and most large diameter irrigation wells that tap it yield 500 to $1,500 \mathrm{gal} / \mathrm{min}$ ( 30 to $95 \mathrm{1} / \mathrm{s}$ ). In the mid-1920's, many small diameter wells were drilled into the zone to provide water for. truck farms. In the Sarasota area, these wells originally flowed as much as $450 \mathrm{gal} / \mathrm{min}(30 \mathrm{1} / \mathrm{s})$. However, water levels in all wells that now tap the zone are below land surface, and we11s require turbine pumps in order to obtain large yields. 
Water levels in this zone fluctuate markedly in response to large seasonal withdrawals for crop irrigation. For example, the marked decline in 1967 (fig. 12) is the result of an unusually dry winter and spring during which time almost constant pumping was required for irrigation. With a return of wet weather in mid-May pumping ceased, and water levels recovered rapidly. During the next growing season, pumping again lowered levels substantial1y.

The hydrograph for observation well Sarasota 9 (wel1 41, fig. 12), a long-term observation we11 open to zones 2,3 , and 4 , shows a net decline in water level during high water-level periods of about $2.5 \mathrm{ft}(0.8 \mathrm{~m}) \mathrm{dur}-$ ing 1960-67. The other wells shown on fig. 12 are open to zones indicated. Water Quality.--In water from zone-4 in the central and coastal areas sulfate and fluoride concentrations generally are in excess of 250 and 1.5 $\mathrm{mg} / 1$, respectively. In the southwestern part of the area, well 5, 1,031 ft $(314 \mathrm{~m}$ ) deep and which is open to the depth interval 80 to $1,031 \mathrm{ft}$ (73 to $314 \mathrm{~m}$ ) yields water containing as much as $3,600 \mathrm{mg} / 1$ of chloride.

As with zones 1, 2, and 3, zone-4 yields water of better quality in the northeastern part of the area than elsewhere in the area. Of all the wells plotted, numbers 32, 38, 54, 55, and 65 tap zone-4 only. The others tap zones 2,3 , and 4 .

Water in zone-4 in the extreme northeastern part of the area (we11 65, fig. 13) meets EPA quality criteria for public supplies. Elsewhere in the northeastern part, sulfate and fluoride concentrations usually can be maintained below $250 \mathrm{mg} / 1$ and $1 \mathrm{mg} / 1$, respectively, if wells are constructed so that water from zone-4 is diluted with water from zones 2 and 3 . 


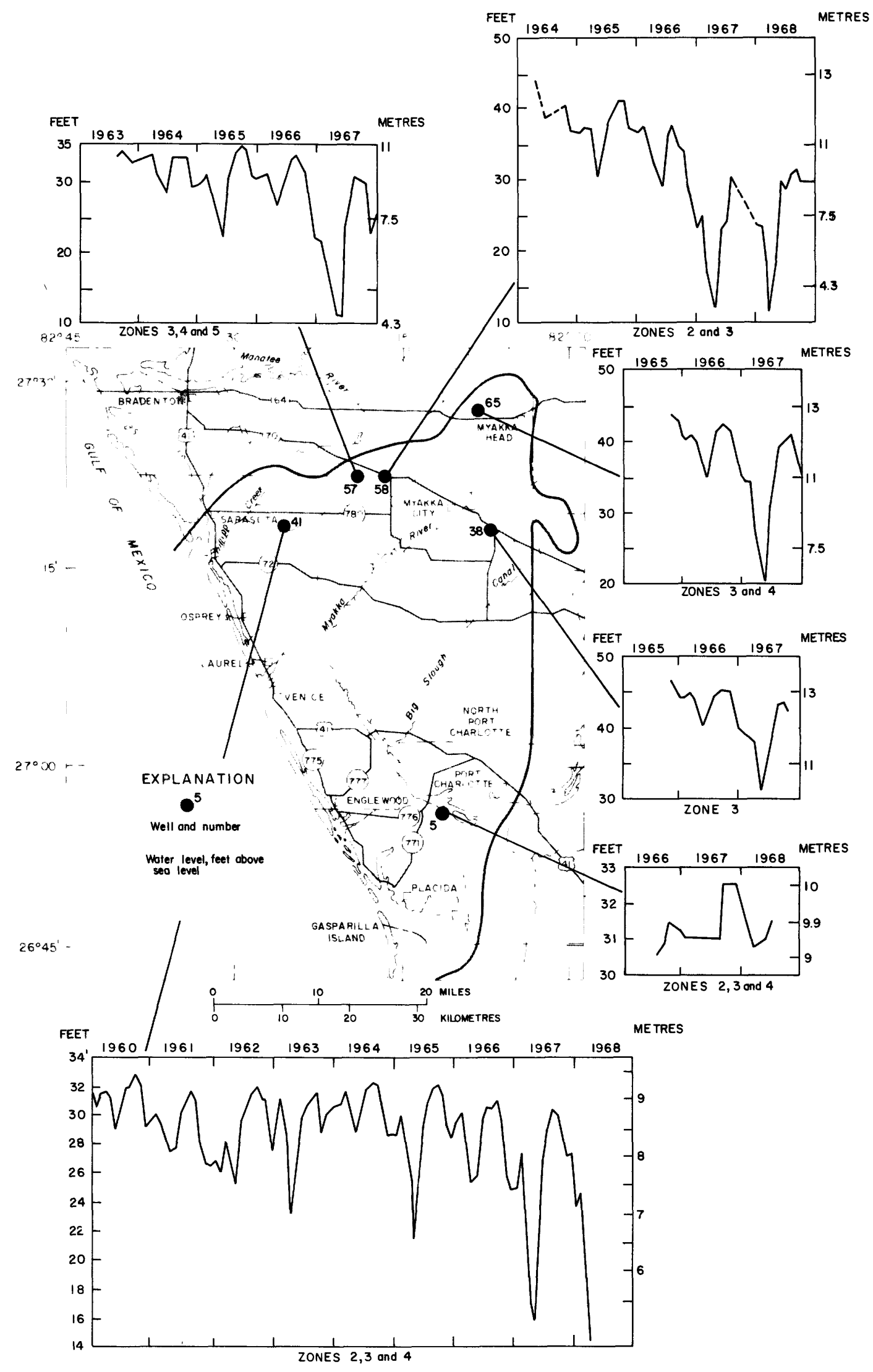

FiguRE 12,--HYDROGRAPHS OF SELECTED OBSERVATION WELLS TAPPING ZONES $2,3,4$, AND 5. 


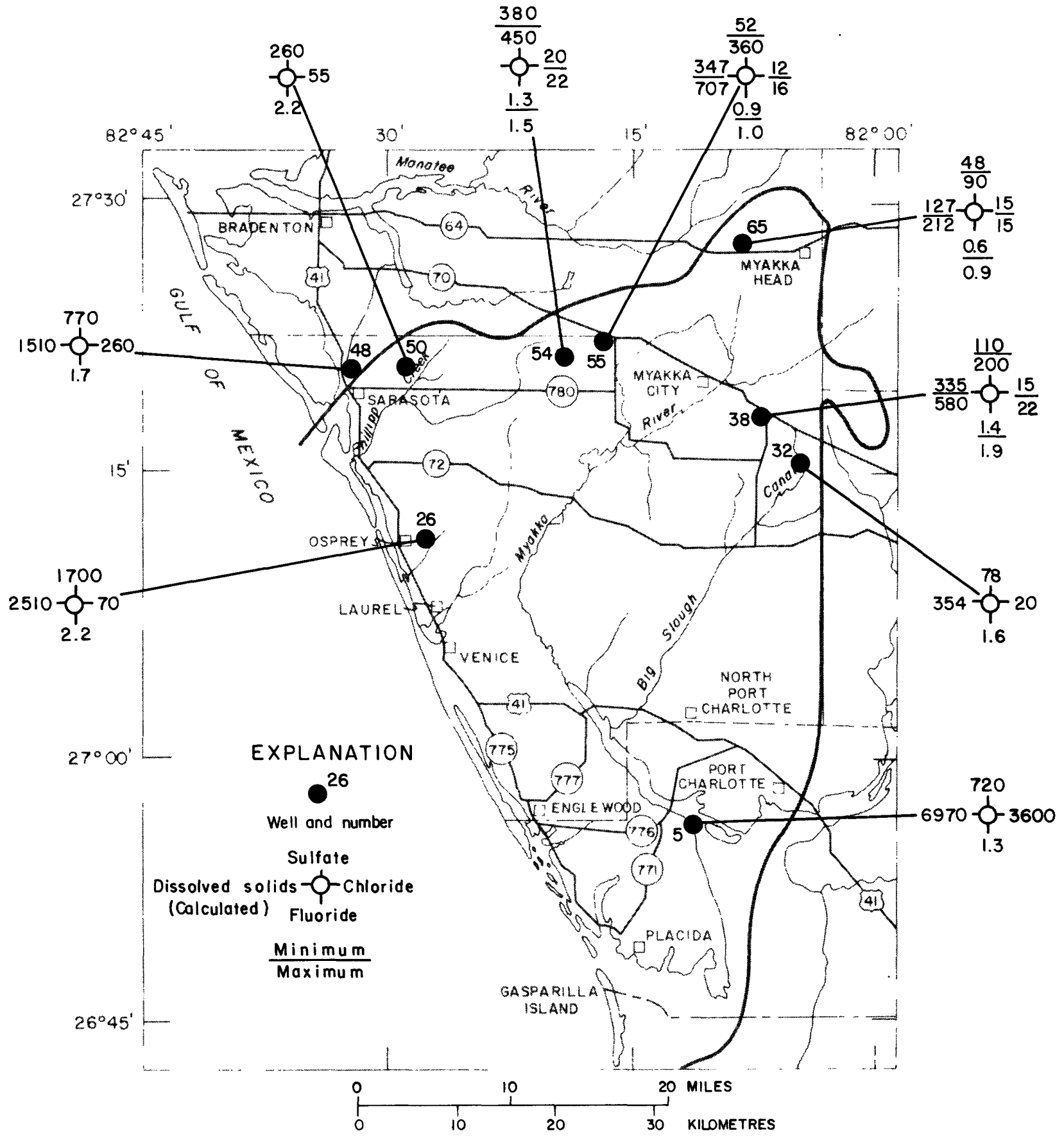

FIGURE 13,--CHEMICAL QUALITY OF WATER FROM ZONE-4 (WELLS 32, 38, 54, 55, AND 65) AND COMPOSITE CHEMICAL QUALITY OF WATER FROM Z.ONES 2, 3, AND 4 (WELLS $5,26,48$, AND 50), 
Water levels in this zone fluctuate markedly in response to large seasonal withdrawals for crop irrigation. For example, the marked decline in 1967 ( $\mathrm{fig} .12$ ) is the result of an unusually dry winter and spring during which almost constant pumping was required for irrigation. With a return of wet weather in mid-May pumping ceased, and water levels recovered rapidly. During the next growing season, pumping again lowered levels substantially.

The hydrograph for observation well Sarasota 9 (wel1 41, fig. 12), a long-term observation we11 open to zones 2,3 , and 4 , show a net decline in water level during high water-level periods of about $2.5 \mathrm{ft}$ $(0.8 \mathrm{~m})$ during 1960-67. The other wells shown on fig.12 are open to zones indicated.

Water Quality.--In water from zone-4 in the central and coastal areas sulfate and fluoride concentrations generally are in excess of 250 and $1.5 \mathrm{mg} / 1$, respectively. In the southwestern part of the area, we11 5, $1,031 \mathrm{ft}(314 \mathrm{~m})$ deep and which is open to the depth interva1 80 to $1,031 \mathrm{ft}(73$ to $314 \mathrm{~m}$ ) yields water containing as much as $3,600 \mathrm{mg} / 1$ of chloride.

As with zones-1-3, zone-4 (fig.13) yields water of better quality in the northeastern part of the area than elsewhere in the area. of all the we11s plotted, numbers $32,38,54,55$, and 65 tap zone-4 only. The others tap zones 2, 3, and 4 .

Water in zone-4 in the extreme northeastern part of the area (we11 65, fig. 10) meets EPA criteria for public supplies. Elsewhere in the northeastern part, sulfate and fluoride concentrations usually can be maintained below $250 \mathrm{mg} / 1$ and $1 \mathrm{mg} / 1$, respectively, if wells are constructed so that water from zone-4 is diluted with water from zones 2 and 3. 
On the basis of water-quality data from wells 5,26 , and 48 in the southwestern one-third of the area, the water from zone-4 is unsuitable for any purpose except perhaps limited irrigation, cooling, or sanitary use. In the peninsula, no wells produce from this zone because of the poor water quality.

Most of the older supply wells of the city of Sarasota tap zones 2, 3, and 4. The analysis of water from well 48 (fig. 13 and table 4); is typical of the old supply wells and exceeds EPA criteria in dissolved solids, fluoride, sulfate, and chloride for public water supply.

Zone-5

Zone-5 consists of the permeable rock in the Avon Park Limestone"the big water," as many drillers call it. None of the U.S. Geological Survey test wells drilled in the Myakka River basin penetrate this zone. It is the major water-producing unit of the artesian Floridan aquifer throughout southwestern Florida. Zone-5 underlies the entire Myakka River basin area at depths ranging from about 1,000 ft (305 m) below land surface in the north and east to more than $1,500 \mathrm{ft}(460 \mathrm{~m})$ below land surface in the south and southwest. This zone is separated from the over lying zones by the lower part of the Ocala Limestone, which is 300 to 400 ft (100 to $120 \mathrm{~m}$ ) thick and which forms a confining layer of low vertical permeability. Because of the depth to this zone, it is tapped only when large amounts of water are required. 
Table 4.--Analysis of water obtained from well 48 that taps Zones 2, 3, and 4 (Analysis by U.S. Geological Survey; in milligrams per litre except specific conductance, $\mathrm{pH}$, and color. Depth of well, $675 \mathrm{feet}$;

length of casing, 80 feet; location shown on fig. 10).

\begin{tabular}{lclr}
\hline Silica $\left(\mathrm{SiO}_{2}\right)$ & 27 & Nitrate $\left(\mathrm{NO}_{3}\right)$ & .00 \\
Iron (Fe) & .00 & Phosphate $\left(\mathrm{PO}_{4}\right)$ & .00 \\
Calcium (Ca) & 230 & Dissolved solids \\
Magnesium (Mg) & 100 & Calculated & 1,510 \\
Sodium (Na) & 100 & Residue & 1,860 \\
Potassium (K) & 6.6 & Hardness & 990 \\
Bicarbonate $\left(\mathrm{HCO}_{3}\right)$ & 160 & $\begin{array}{l}\text { Specific conductance, micro- } \\
\text { mhos/cm at } 25^{\circ} \text { C }\end{array}$ & 2,000 \\
Sulfate (SO & & & 7.4 \\
Chloride $(\mathrm{C} 1)$ & 770 & pH & 2 \\
Fluoride $(\mathrm{F})$ & 260 & Color &
\end{tabular}


Zone-5 is developed in combination with other zones as a source of water for irrigation wells that yield as much as 1,500 to 2,000 gal/min (95 to $125 \mathrm{1} / \mathrm{s}$ ) each. Use of water from the zone follows a pattern that is repeated each year and results in heavy pumping during the spring tomato and melon growing season, which runs from mid-February through mid-May followed by very little pumping from June to September. The amount pumped from zone 5 increases each year. Most of the irrigation withdrawal is confined to the northeastern part of the basin. Each year, growers clear part of the range to grow melons. As payment for land use, the grower ditches and grades the land, and drills an irrigation well, which is usually 12 in $(305 \mathrm{~mm})$ in diameter and has a pumping capacity of $2,000 \mathrm{gal} / \mathrm{min}$ (125 1/s). During the growing season (about 3 months) the well is pumped continuously. As soon as the crop is harvested, the land and the well revert to the cattle-ranch owner, who then installs a permanent pump that is used to irrigate grass on the abandoned melon fields:

For economic reasons, wells are usually cased only to the first hard-rock unit, usua11y less than 200 feet $(60 \mathrm{~m})$ and the rest of the hole is open to several aquifer zones. After initial use for melon irrigation the wells may stand idle for months or even years before being pumped again. During this time, uncontrolled mixing of water of different quality occurs in the wells. Water moves in the wells from zones with higher head into zones with lower head. For example, water may move from zone-5, up the we11 bore, into zone-4, which has a lower head. Such mixing can cause the quality of water in the upper zone to deteriorate. 
Water quality--Water in zone 5 is more highly mineralized than that in zones 1-4. Except for the extreme northeastern part of the area, the sulfate and generally the fluoride concentrations exceed the water-quality criteria of EPA for public supply (fig. 14 and page 28). In the southern part of the Myakka River basin area the chloride concentration in water from zone 5 also exceeds the limit. (See we11 5, fig. 14.) Several attempts were made to use water from zone 5 along the northern part of the study area for municipal water supply, but its mineral concentration was too high for such use.

Water with less than $300 \mathrm{mg} / 1$ of dissolved solids is available in zone 5 in the extreme northeastern part of the Myakka River basin area. Well 67 yields water of excellent quality as shown in figure 14 . Between this well and Myakka City, water from zone 5 is of acceptable quality for public supplies except for the fluoride concentration, which in places is as much as $2.0 \mathrm{mg} / 1$. In water from zone 5 in the east-central part of the area sulfate and fluoride concentrations are as much as 390 and $1.8 \mathrm{mg} / 1$.

In 1957 the city of Sarasota attempted to develop zone 5 to furnish water for a swimming pool, but found that at a depth of 1,240 feet $(378 \mathrm{~m})$ the water was too saline for use. In 1962 , the city of Sarasota again attempted to develop a water supply from this zone by drilling to 1,232 feet $(376 \mathrm{~m})$. However, at that depth the well yielded water whose dissolved solids concentration was more than $3,100 \mathrm{mg} / 1$. When plugged back to about $1,000 \mathrm{ft}(305 \mathrm{~m})$, this well yielded water of acceptable quality from zone-4, for use as an irrigation well on a golf course. 


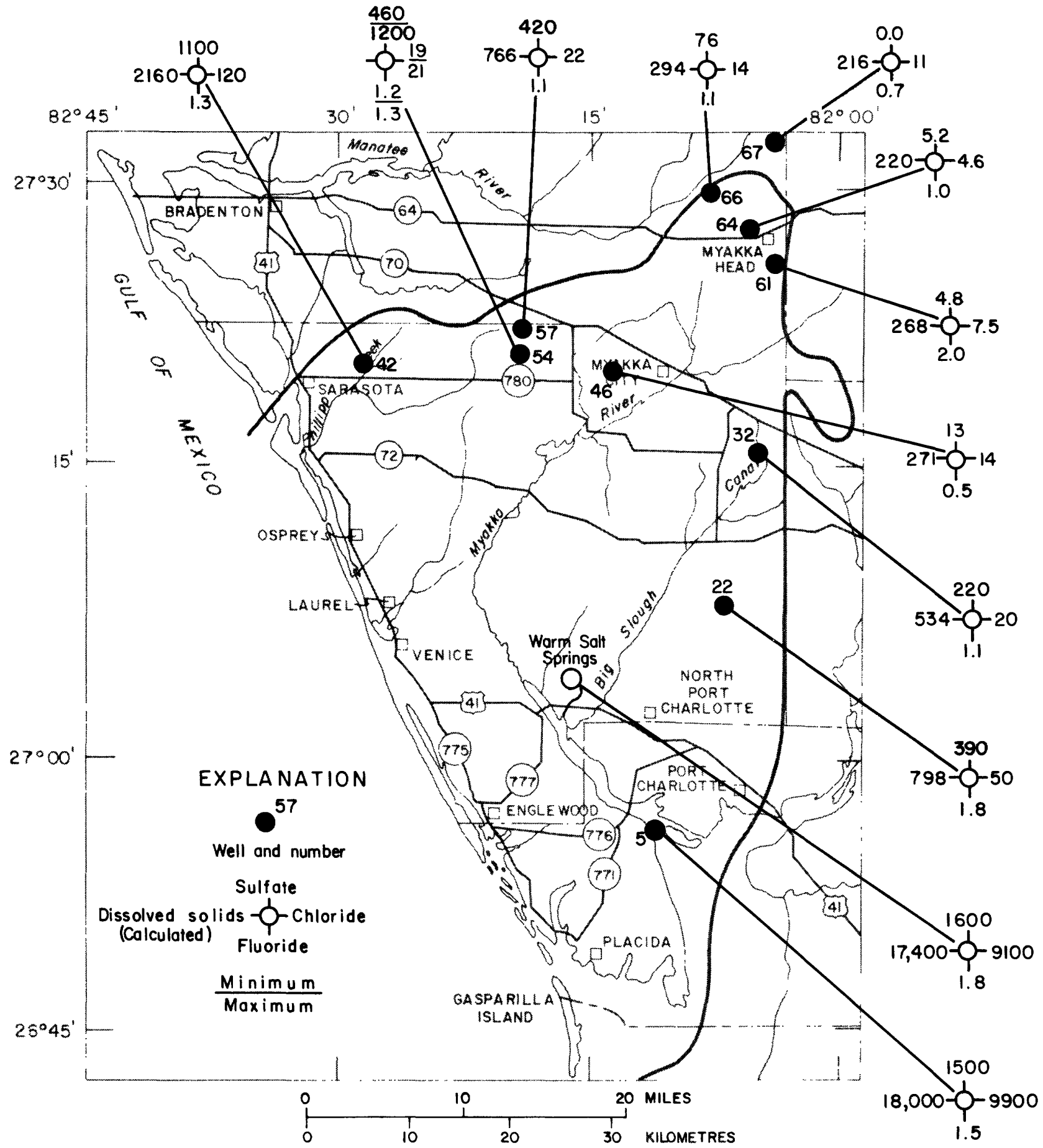

FIGURE 14,--COMPOSITE CHEMICAL QUALITY OF WATER FROM ZONES 2, 3, 4, AND 5 , AND WARM SALT SPRINGS. 
We11 54, city of Sarasota test well KME 1, at a depth of: 1,462 ft $(446 \mathrm{~m})$ yielded water from zone-5 with a minimum chloride concentration of only $19 \mathrm{mg} / 1$. Its sulfate concentration, however, was over $450 \mathrm{mg} / 1$. When the well was deepened to $1,493 \mathrm{ft}$ (455 m) and was open to the interval 1,462-1,493 ft (446-455 m) it yielded water containing only $21 \mathrm{mg} / 1$ of chloride but sulfate concentration increased nearly three-fold, to $1,200 \mathrm{mg} / 1$.

Water from Warm Salt Springs probably originates in part from zone-5; the water temperature $\left(30^{\circ} \mathrm{C}\right)$ and the quality characteristics of the water (fig. 14) are similar to water from well 5. Table 5 shows analyses of water from the springs and well 5, which is near the mouth of the Myakka River. Similarities of the major constituents in water from both sources indicate that the water is originating from either zone-5 or from zones 2-5. 
TABLE 5.--Analyses of water from Warm Salt Springs and we11 5. (Analyses by U.S. Geological Survey; in milligrams per litre except specific conductance, $\mathrm{pH}$, and color.)

Cattle Dock

Warm Salt Springs

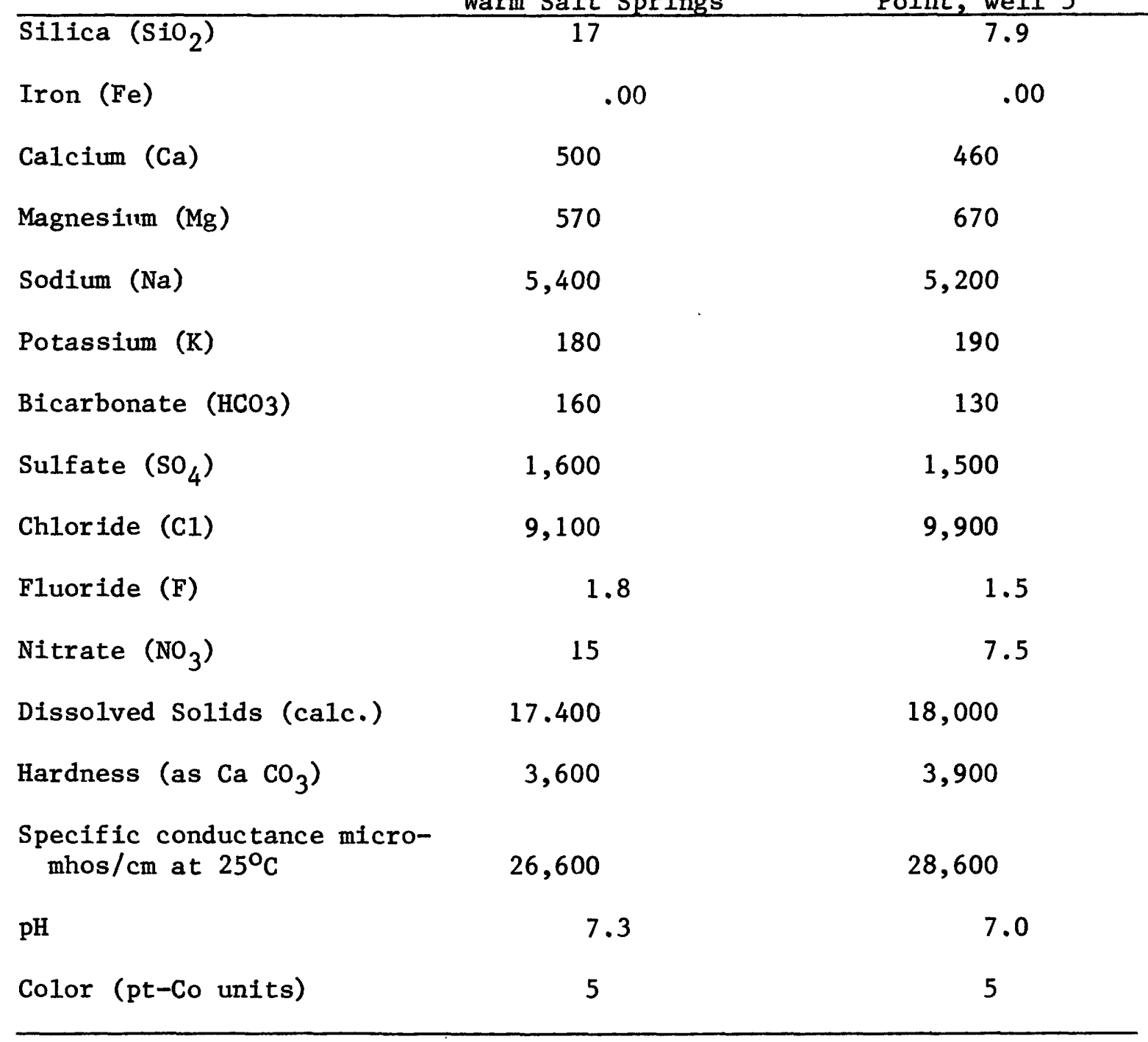




\section{Potentiometric surface}

The configuration of the potentiometric surface of the artesian zones 2-5 at the end of a dry and a wet period is shown on figures 15 and 16, respectively. Most of the we11s used in preparing these maps were open to zones $2-4$, and a few to zones 2-5. The water level in each well represents the composite head in the zones penetrated by the we11. The maps show that the regional gradient and principal direction of flow is from east to west. The potentiometric surface was higher in November 1966 than in June 1966: recharge from heavy summer rains and cessation of pumping for irrigation during the rainy season cause water levels to rise. Where heavy pumping marked1y lowered the potentiometric surface (fig. 15) troughs in the surface were created.

In much of the area water levels in wells that tap zones 3-5 rise above land surface and at the end of the rainy season wells will flow. This is the area of artesian flow of figure 16. Many flowing wells were observed during the investigation. 


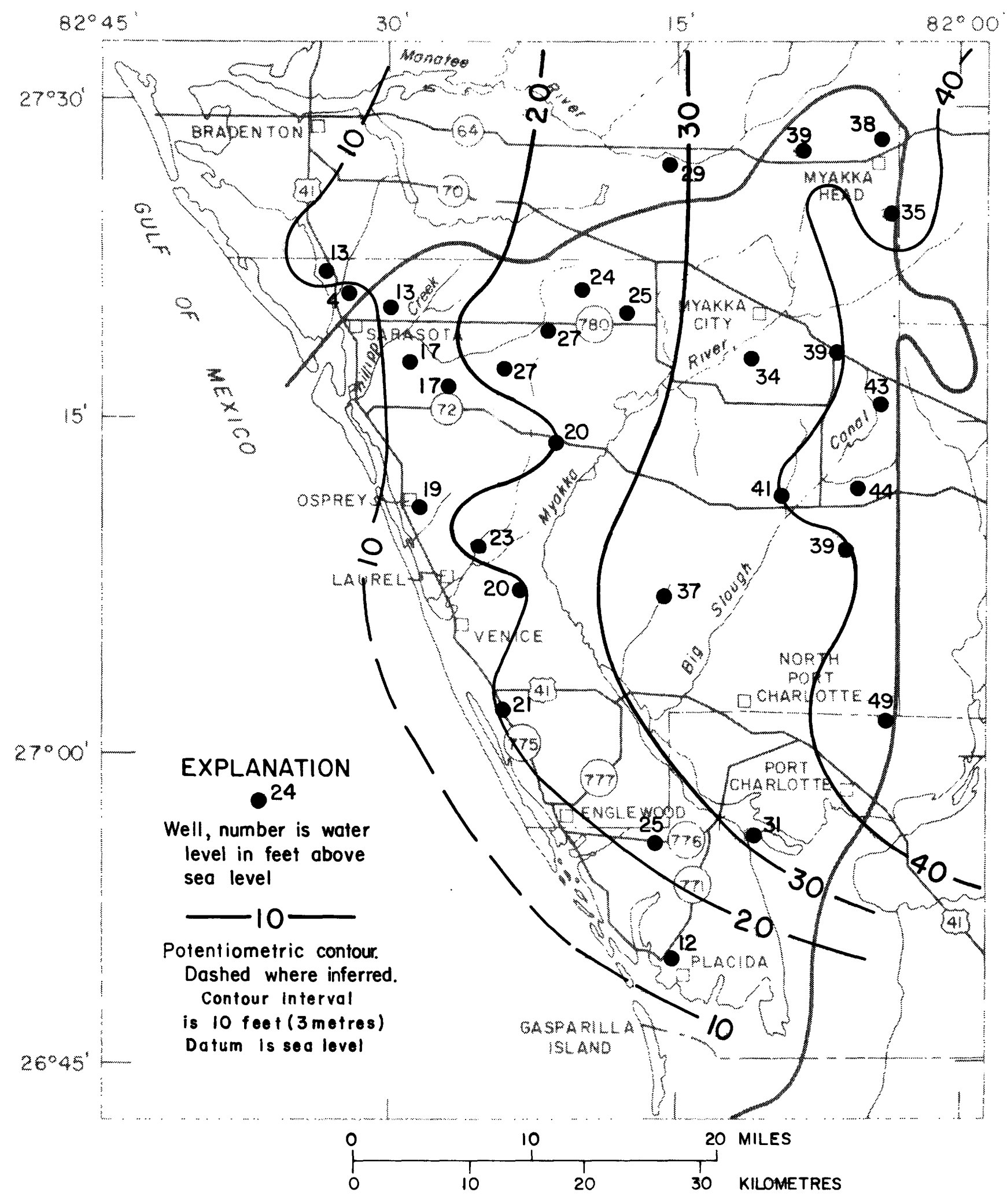

FIGURE 15, --GENERALIZED CONFIGURATION OF COMPOSITE POTENTIOMETRIC SURFACE OF ZONES 2, 3, 4, AND 5 IN JUNE 1966 


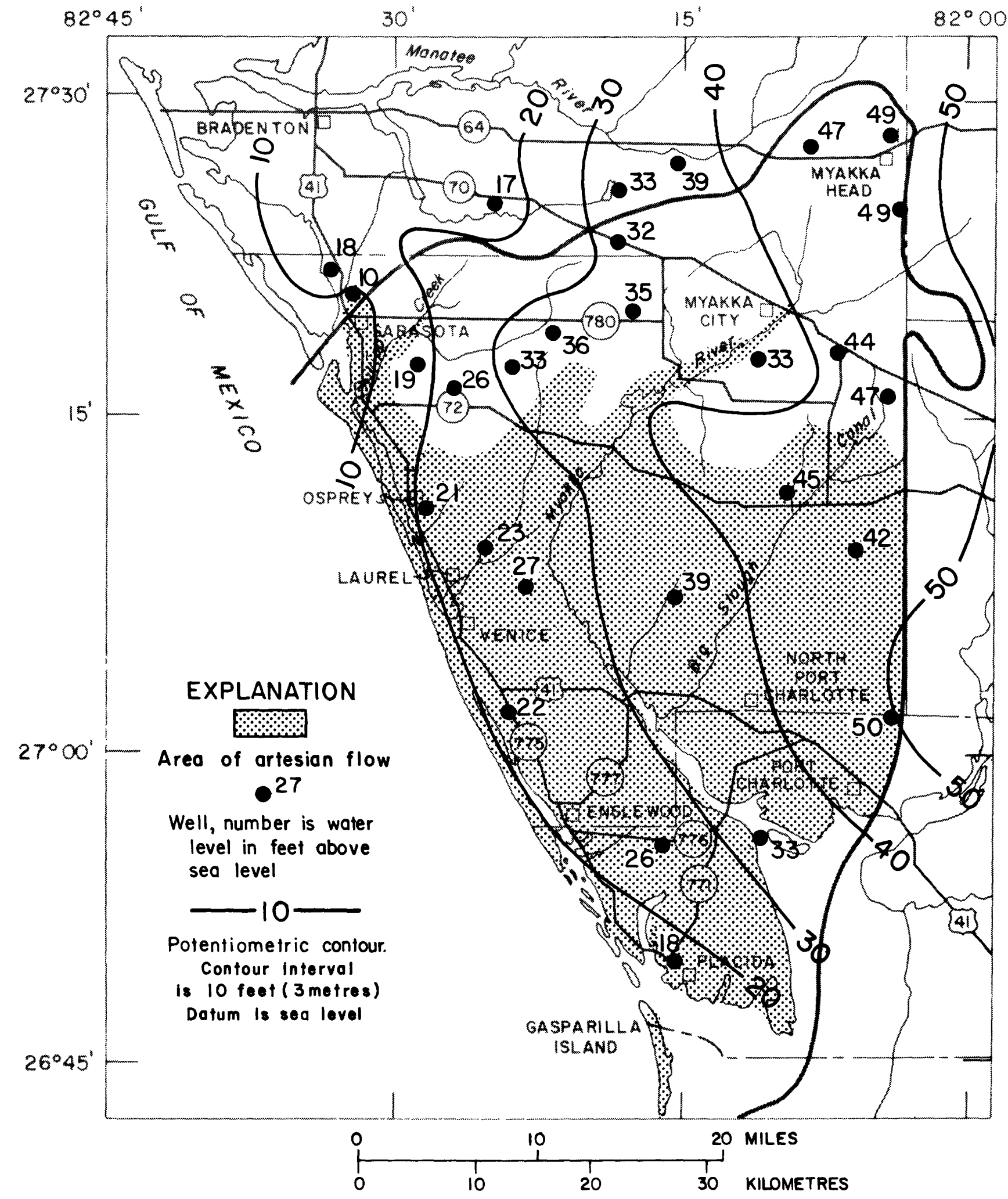

FIGURE 16, --GENERALIZED CONFIGURATION OF COMPOSITE POTENTIOMETRIC SURFACE OF ZONES 2, 3, 4, AND 5 IN NOVEMBER 1966 AND AREA OF ARTESIAN FLOW. 


\section{Surface Water}

\section{Streamflow}

Most of the streams in the Myakka River basin area have sma11 drainage basins, are of short channel length, and do not yield high volumes of flow. The yields of many, however, are sufficient that they represent a potential source of fresh water to supplement the watersupply needs of the urbanizing coastal zone. The scarcity of sites suitable for impoundments along most streams will severely limit the development of streamflow as an adjunct to the ground-water supply--to satisfy water demand during droughts.

F1ippo and Joyner (1968) discuss low-flow characteristics of streams in the Myakka River basin area such as frequency and magnitude flow duration, and water quality, and they analyze the draft-storage relations of Upper and Lower Myakka Lakes. The text that follows, including the section on water quality, is a summary of their findings.

Streamflow data, collected since 1936 in the area, indicate that a11 non-tidal reaches of streams ceased natural flows during at least five droughts since 1938. Many of these non-tidal reaches go virtually dry late in the spring during most years. Upper and Lower Myakka Lakes, through which the Myakka River flows, occupy two of the largest natural depressions in the area and their aggregate storage capacity at $16 \mathrm{ft}$ $(5 \mathrm{~m})$ and $14 \mathrm{ft}(4 \mathrm{~m})$ above sea level is approximately 8,100 acre-ft $\left(3300 \mathrm{ha}^{2}\right)$. The average discharge at a stream gaging station located between the two lakes is $266 \mathrm{ft}^{3} / \mathrm{s}\left(7.5 \mathrm{~m}^{3} / \mathrm{s}\right)$ or about 193,000 acre-ft 
$\left(78,000 \mathrm{ha}^{2}\right)$. Draft-storage studies indicate that the Upper and Lower Myakka Lakes--if maintained at 14 and $10 \mathrm{ft}$ ( 4 and $3 \mathrm{~m}$ ) above ms 1, respectively--could provide a continuous draft of $6.5 \mathrm{Mgal} / \mathrm{d}\left(0.28 \mathrm{~m}^{3} / \mathrm{s}\right)$ over a 30-year drought and $10 \mathrm{Mgal} / \mathrm{d}\left(144 \mathrm{~m}^{3} / \mathrm{s}\right)$ over a 20-year drought.

A feasibility study of the lower Myakka River would allow exploring the possibility of impounding this stream as a supply for the southeastern part of the area. Large quantities of water are stored in the channel of the lower Myakka River. A low-head dam would keep saltwater out of the stream and retain the freshwater for use during droughts.

60 


\section{Water Quality}

During the dry season, streamflow is maintained by ground-water discharge, and, as a result, chloride, sulfate, and dissolved solids concentrations and the hardness of the water are above drinking water standards for some streams. During the wet season, streamflow is mainly from overland runoff, and the concentrations of these constituents and the hardness of the water are minimum. The range in concentrations of constituents or in characteristics is shown in table 6 for water from 23 surfacewater sampling sites. The location of these sites is shown on figure 17. During the wet season, water from swamps and marshes flows into the streams, and the color of the water is then maximum. Flow from swamps and marshes diminished or ceases during the dry season, at which time the color of the stream is least.

During the dry season most of the streams contain water whose hardness is more than $180 \mathrm{mg} / 1$; during the rest of the year the hardness is less than $180 \mathrm{mg} / 1$ for most of the streams. The hardness of water in streams in the coastal areas generally is greater than in those inland. The upper reaches of the Myakka River contain the softest water in the area.

The chloride, sulfate, and dissolved-solids concentrations of water from most of the streams sampled during the study generally are less than 250,250 , and $500 \mathrm{mg} / 1$. In the coastal area the chloride concentration of all tidal-affected streams generally is more than $250 \mathrm{mg} / 1$. Barriers in Phillipi Creek and Big Slough prevent upstream movement of saltwater. 


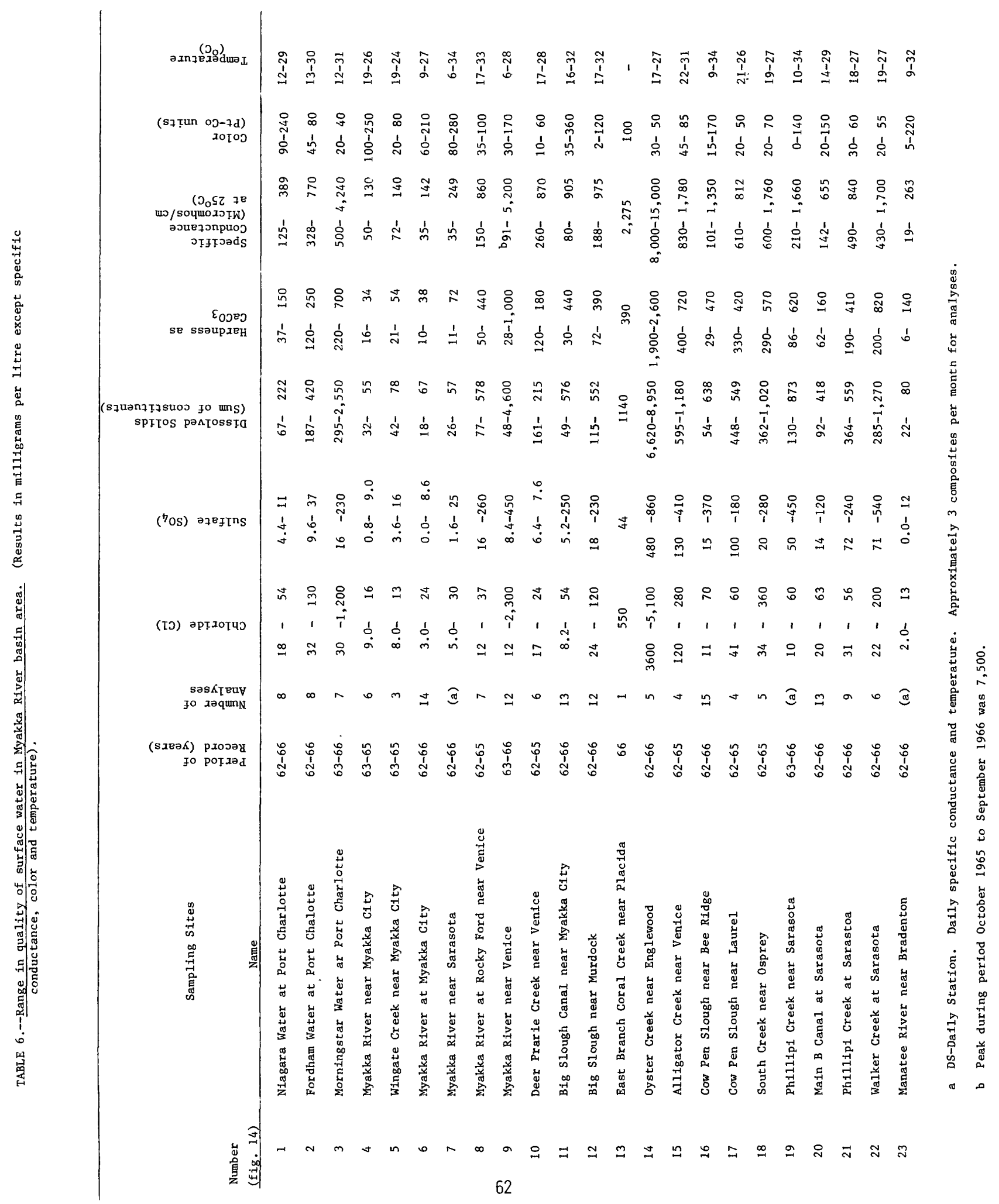




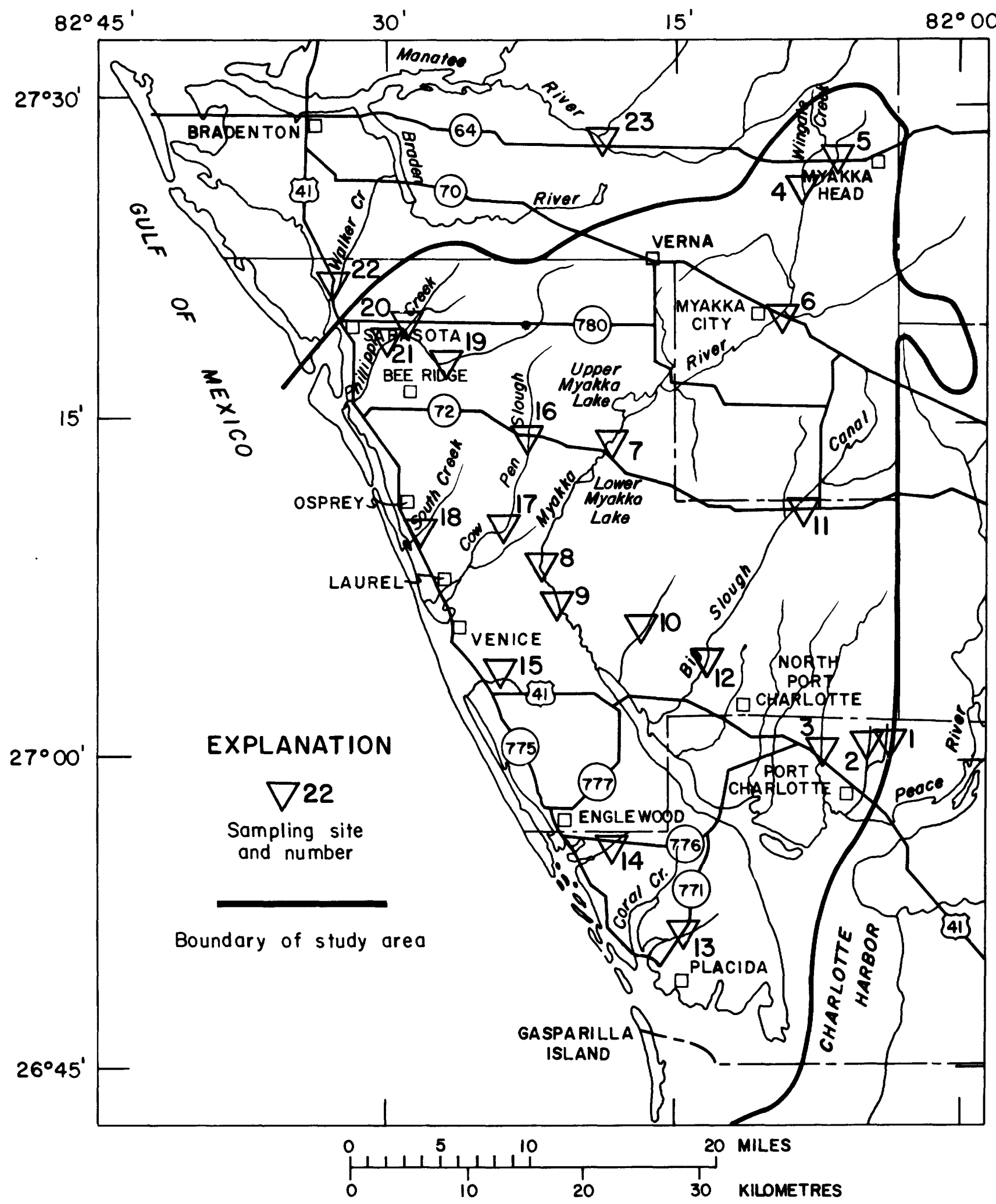

FIGURE 17,--SURFACE-WATER SAMPLING SITES, 


\section{Lakes}

The principal two lakes in the Myakka River basin area are the Upper and Lower Myakka Lakes. Both occupy shallow depressions; the sha1lowest parts contain a heavy growth of aquatic vegetation. On lake bottoms in the deeper parts of the lakes are soft layers of decaying organic material. The lake bottoms around the edges and at the inlets are firmly packed sand.

The two lakes have been considered from time to time for use as a public water supply. Bt maintaining a level of $14 \mathrm{ft}(4 \mathrm{~m})$ above mean sea level at the upper lake and $10 \mathrm{ft}(3 \mathrm{~m})$ at the lower lake, about 4,600 acre-ft $\left(1,860 \mathrm{ha}^{2}\right)$ of water could be stored. The area also contains hundreds of sma11 lakes and ponds that have a surface area 1ess than 200 acres ( $80 \mathrm{ha}$ ) each. Most of these are in the western ha1f of the area. They are shallow and may go dry during moderate droughts. Levels of some of the larger lakes in urbanized areas are maintained by pumped ground water during extended dry periods. 
Springs

Few springs are in the Myakka River basin area. Nearly all issue from solution cavities that are open to zones of artesian flow. Warm Mineral Springs (Warm Salt Springs) is in Sarasota County, $5 \mathrm{mi}(8 \mathrm{~km})$ northwest of North Port Charlotte (fig. 14). The spring head is a pool about $250 \mathrm{ft}(75 \mathrm{~m})$ in diameter and $167 \mathrm{ft}(57 \mathrm{~m})$ deep (Ferguson and others, 1947, p. 148). The spring discharges to Salt Creek, a tributary of the Myakka River, at a rate of about $10 \mathrm{ft}^{3} / \mathrm{s}\left(0.3 \mathrm{~m}^{3} / \mathrm{s}\right)$. The water temperature varies little from $86^{\circ} \mathrm{F}\left(30^{\circ} \mathrm{C}\right)$ and the chloride concentration is about $9,300 \mathrm{mg} / 1$. The spring is used for mineral baths.

Little Salt Spring is $2.0 \mathrm{mi}(3.2 \mathrm{~km})$ northeast of Warm Mineral Springs. The spring flows into a circular pool about $250 \mathrm{ft}$ (75 m) in diameter. Spring discharge measured between April 1946 and June 19.62 , ranged from 0.89 to $1.53 \mathrm{ft}^{3} / \mathrm{s}\left(0.03\right.$ to $\left.0.04 \mathrm{~m}^{3} / \mathrm{s}\right)$. The flow has been reported as 1 ow as $0.17 \mathrm{ft}^{3} / \mathrm{s}\left(0.005 \mathrm{~m}^{3} / \mathrm{s}\right.$ ) (Ferguson and others, 1947, p. 146). Temperature of the water has ranged from $71.6^{\circ}$ to $91.4^{\circ} \mathrm{F}\left(22^{\circ}\right.$ to $\left.33^{\circ} \mathrm{C}\right)$. The chloride concentration of the spring water is about $1,300 \mathrm{mg} / 1$, and the dissolved-solids concentration is about $3,000 \mathrm{mg} / 1$. 
Pinehurst Spring is on the bank of a small bayou on Little Sarasota Bay about $7.0 \mathrm{mi}$ south of Sarasota. A flow of $0.006 \mathrm{ft} / \mathrm{s}$ $\left(0.0003 \mathrm{~m}^{3} / \mathrm{s}\right)$ was measured on April 30, 1946, and a flow of as much as $0.11 \mathrm{ft}^{3} / \mathrm{s}\left(0.003 \mathrm{~m}^{3} / \mathrm{s}\right)$ has been reported (Ferguson and others, 1947, p. 147). In recent years, discharge has decreased as water levels in the artesian aquifers tapped by the spring have declined. The quality of water from the spring has gradually deteriorated with the lowering of water levels. The chloride and sulfate concentrations of the spring water were reported to be 34 and $9.4 \mathrm{mg} / 1$ in 1943. On June 15, 1962, the chloride and sulfate concentrations of the water were 106 and $39 \mathrm{mg} / 1$.

A seepage zone or spring line occurs along the Myakka River valley about $2.0 \mathrm{mi}(3.2 \mathrm{~km})$ southwest of Myakka City. The seeps issue from the top of a hardpan in the water-table aquifer that crops out in the valley wall. At least one of these seeps may be perennial. The flow of each individual seep is probably less than 0.004 $\mathrm{ft}^{3} / \mathrm{s}\left(0.0001 \mathrm{~m}^{3} / \mathrm{s}\right)$

A deep hole, nearly circular, occurs in the bed of the Myakka River about $150 \mathrm{ft}(46 \mathrm{~m})$ to the right from midstream near the outlet to Lower Myakka Lake. On July 15, 1965, the hole was about $300 \mathrm{ft}(90 \mathrm{~m})$ in diameter at the top and $124 \mathrm{ft}(38 \mathrm{~m})$ deep. The nearly vertical walls of this opening angle slightly northward from top to bottom and the hole is 40 to $50 \mathrm{ft}(12$ to $15 \mathrm{~m})$ in diameter for most of its depth. The flow issuing from the hole probably ceases when the stage of the Myakka River is exceptionally high and during extended low-flow periods. At times the flow may be as much as 1.5 $f t^{3} / \mathrm{s}\left(0.04 \mathrm{~m}^{3} / \mathrm{s}\right)$. 
WATER USE

About 16.5 billion gallons $(62.5$ million cubic metres) of ground water were withdrawn in the Myakka River basin area in 1965 . This withdrawal is equivalent to an average pumpage of about $45 \mathrm{Mgal} / \mathrm{d}$ $\left(2 \mathrm{~m}^{3} / \mathrm{s}\right)$. Because of the seasonal pattern of water use, probably 40 percent of the annual total use occurs during the dry spring. More water is used for irrigation than for all other uses combined. of the irrigation use, the largest single use is for pasture irrigation. Public supply is about 35 percent of total use and industrial commercial use is less than 1 percent (table 7).

In 1965, 23 major public-supply systems used ground water as a source in the Myakka River basin area; all of these were in Sarasota County. The area also has many small systems which serve less than 100 units, such as trailer parks and motels. The quantities of water used by these systems are included in the estimate of use for public supply. Sarasota and Venice, the two principal public-supply systems, withdrew about 1.4 and 0.2 billion gallons (5.3 and 1.1 million cubic metres), respectively during 1965 (fig. 15). Of the 120,000 persons living in the area in 1965 about 75,000 were served by private wells. On the basis of an estimated per capita use of 120 gallons (450 1itres) per day, the daily rural domestic use was $9 \mathrm{Mgal} / \mathrm{d}$ $\left(0.4 \mathrm{~m}^{3} / \mathrm{s}\right)$. 
Table 7.--Estimated ground-water pumpage in the Myakka River basin area in 1965.

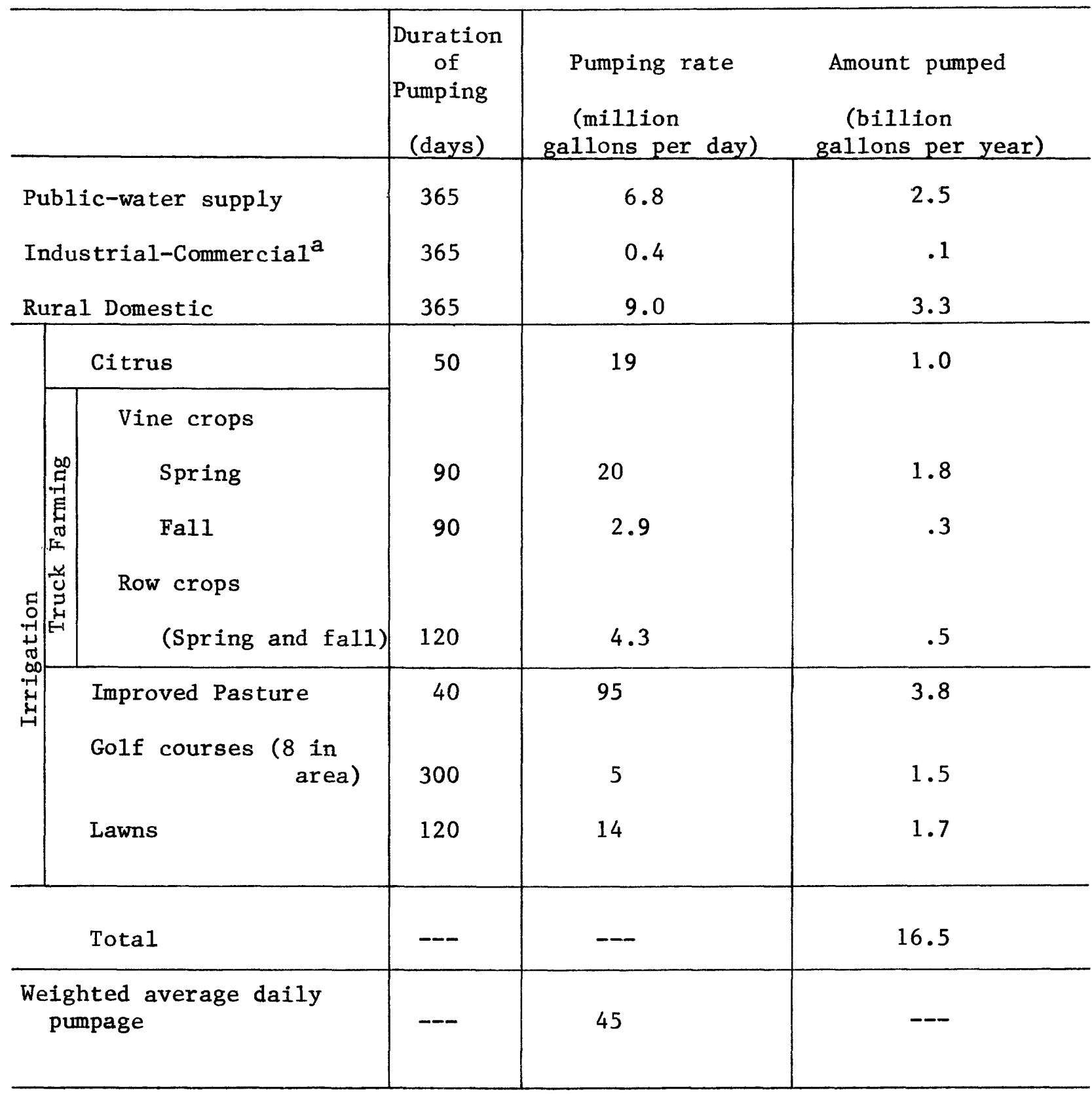

a/ Principally used for cooling air-conditioner condensers. 


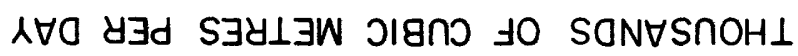

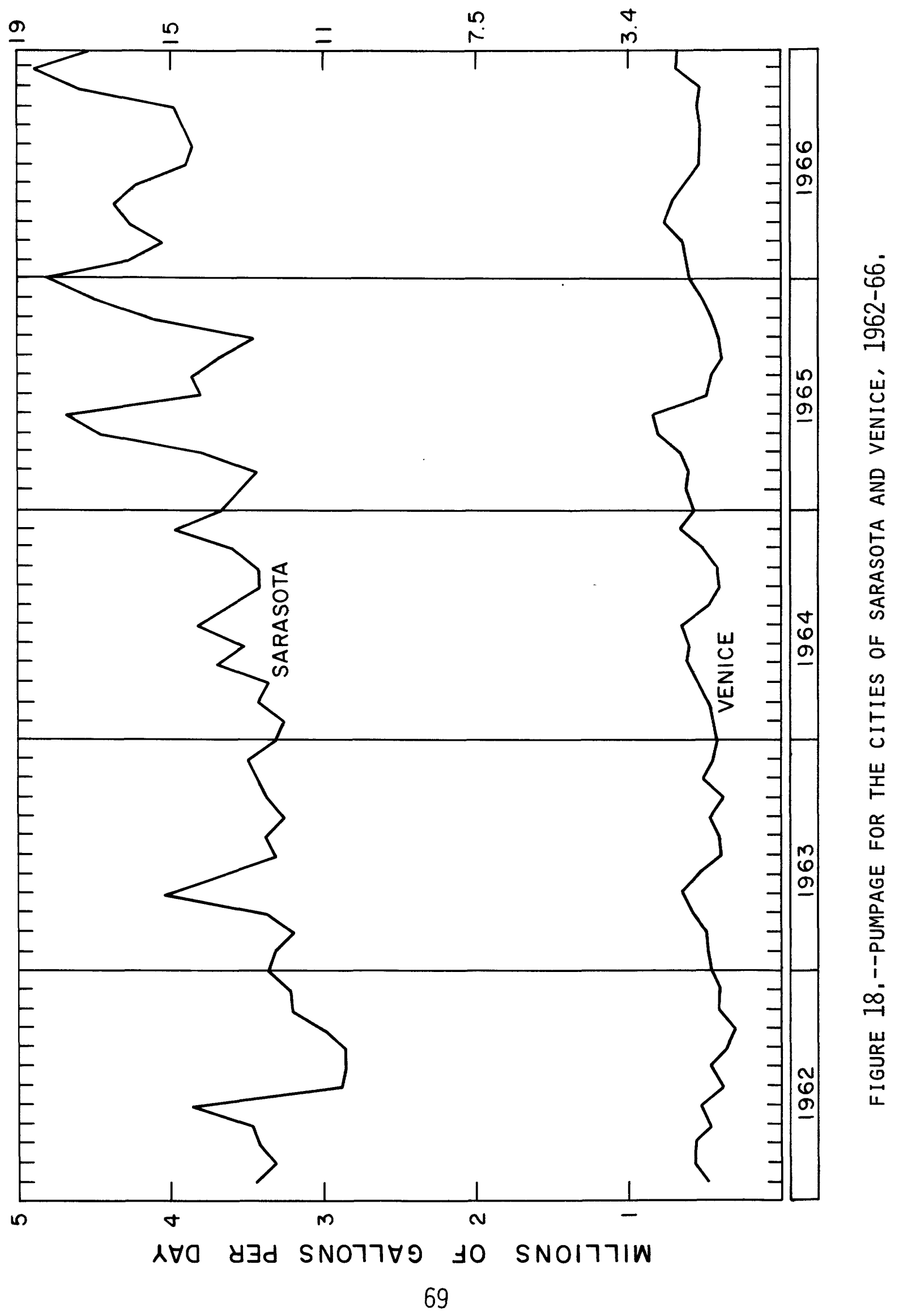


The amount of ground water used for irrigation was grouped into 5 categories: citrus, truck farming, improved pasture, golf courses, and lawn watering. In 1965, about 4,000 acres (1,600 ha) of citrus were irrigated. Of this amount, half was in Sarasota County and half in Manatee County. The rate of application for citrus was estimated to be 5,000 gal/min (315 1/s) per 8-hr day for 500 acres (200 ha) during the irrigation season.

Truck farmers in the area plant a spring and fall vine crop. The 1965 spring vine crop was about 3,500 acres ( $1,400 \mathrm{ha}$ ) of tomatoes, melons, squash, and cucumbers. These crops were irrigated continuously 24 hours a day for approximately 90 days at the rate of about $2,000 \mathrm{gal} / \mathrm{min}$ (126 l/s) or $2.9 \mathrm{Mgal} / \mathrm{d}$ per 500 acres (200 ha). The $1965 \mathrm{fall}$ vine crop consisted of about 500 acres ( $200 \mathrm{ha}$ ) of tomatoes irrigated at the same rate for the same duration. Row crops are planted on muckland in September, and final harvesting is in mid-May. These crops are irrigated only occasionally during the drier part of the season.

The same amount of water is used for irrigation of improved pasture as for vine-crop irrigation: $2,000 \mathrm{gal} / \mathrm{min}(126 \mathrm{l} / \mathrm{s})$ or $2.9 \mathrm{Mgal} / \mathrm{d}$ per 500 acres (200 ha). The pasture irrigation season lasts about 40 days each year. Within the study area in 1965, about 12,500 acres (5,100 ha) of improved pasture in Manatee County and 4,000 acres (1,600 ha) in Sarasota County were irrigated. 
Golf courses use large amounts of water for irrigation of fairways and greens. Within the study area, Sarasota County has seven courses and Charlotte County one. An irrigated 18-hole golf course requires about $400 \mathrm{gal} / \mathrm{min}(25 \mathrm{1} / \mathrm{s})$ or $0.6 \mathrm{Mgal} / \mathrm{d}$ for 300 days each year, the daily golf-course use in the area for those 300 days is $5 \mathrm{Mgal} / \mathrm{d}\left(0.2 \mathrm{~m}^{3} / \mathrm{s}\right)$.

Many home owners have individual wells to supply water for lawn irrigation and automatic sprinkler systems. The following data were used to estimate the water use for this purpose:

Total population

3 persons per dwelling

$1 / 5$ acre per dwelling lot

50 percent of acreage consist of $1 \mathrm{awn}$

60 percent of homeowners irrigate
120,000

40,000 dwe1lings

8,000 acres (3200 ha) occupied

4,000 acres (1600 ha) of lawn

2,400 acres (970 ha) irrigated

On the average, lawns in the area require irrigation about 120 days per year. The application rate is about $50 \mathrm{gal} / \mathrm{min}(3.2 \mathrm{l} / \mathrm{s}) \mathrm{per}$ acre applied 2 hours per day, or about $0.006 \mathrm{Mgal} / \mathrm{d}$ per acre.

In 1965 only about $2.5 \mathrm{Mgal} / \mathrm{d}\left(0.1 \mathrm{~m}^{3} / \mathrm{s}\right)$ of surface water was used for public water supply and pasture irrigation. 


\section{WATER PROBLEMS}

The water problems in the Myakka River basin area are varied, complex, and often interrelated. They include flooding, inadequate or excessive drainage, inadequate supply of water of suitable quality, and deterioration of the supply by pollution and saltwater encroachment. Some problems are the result of man's alteration and stressing of the environment and his need for large quantities of water of good quality. Where serious conflicts in consumptive use of a limited supply are anticipated, priorities of use should eventually be established. This would involve legal, economic, and sociological as well as hydrologic considerations. 


\section{Floods}

Much of the Myakka River basin area is subject to flooding when rainfall is exceptionally heavy. Ditching has accelerated drainage from many parts of the area that would experience temporary flooding during periods of normal rainfall. The urbanizing coastal area also is subject to flooding when tides are abnormally high. The problems associated with flooding and the delineation of flood-prone areas are beyond the scope of this study. Estimates of the magnitude and relative occurrence of flood discharges can be obtained from a regional flood study by Barnes and Golden (1966).

When rainfall is heavy, the capacity of some natural channels and canals is inadequate for rapid conveyance of flood waters, thereby resulting in widespread flooding of lowlands. These flood-prone areas may be inundated for as long as 1 month. About one-third of the land below an altitude of $40 \mathrm{ft}(12 \mathrm{~m})$ is subject to this type of flooding. The coastal areas below $10 \mathrm{ft}(3 \mathrm{~m})$ are also vulnerable to flooding caused by exceptionally high tides generally above 5 feet. Tidal studies made by the U. S. Army Corps of Engineers (1961) indicate that a tide of 10 to $12 \mathrm{ft}$ ( 3 to $3.7 \mathrm{~m}$ ) may be expected on the average about once every 100 years.

Urban development along these 1ow-1ying coastal areas has expanded rapidly since 1950. At the present stage (1965) of urban development and flood protection, storms of the magnitude of those in 1960 and 1962 are likely to cause major flood damage. 
With the expansion of agriculture into 1ow-1ying areas, annual flood damages have steadily increased. Although drainage of agricultural lands has reduced the incidence of minor flooding, it has also encouraged greater expansion of agriculture onto the flood plains. As a result, by 1960 the estimated average annual flood damage to agriculture in the Phillippi Creek and Cow Pen Slough basins had increased to more than $\$ 100,000$ (U. S. Soil Conservation Service, 1961).

\section{Drainage}

Closely allied to flood problems are those resulting from drainage of the land. Lowlands have been drained to make them available for farming. Also water levels in the water-table aquifer have been lowered to make lowlands habitable, and drainage divides have been crossed by ditches in efforts to improve drainage. As a result, water moves more readily from land to the sea; consequently recharge to the aquifers is reduced. 


\section{Supply}

One of the most pressing problems in the Myakka River basin area is the need for additional public-water supply of suitable quality to meet the requirements of a growing population. In addition, irrigation requirements are also increasing. Suitable sites are generally not available for the development of surface-water supplies, and ground water of suitable quality is restricted to specific aquifer zones in certain areas. Thus, the competition for water that meets drinking-water standards is keen. To some extent this problem can be alleviated in topographically suitable areas where some creeks can be impounded to maintain water levels in shallow aquifers developed for public supplies. For example, the impoundment on Coral Creek (fig. 17) about 1 mile from a well field, maintains high water levels in the well field and curtails saltwater intrusion in the Immediate area. Oyster Creek and Gottfried Creek near Englewood may be suitable for similar types of water-supply development and control. Sampling site 14 (fig. 17) is on Oyster Creek; Gottfried Creek is about 1 mile north. 


\section{Contamination}

Freshwater supplies in the Myakka River basin area are subject to contamination as a result of intrusion of saltwater mixing of ground water of poorer quality with that of better quality by interaquifer flow, and pollution of streams and aquifers by man-made wastes. No widespread intrusion of saltwater due to overpumping of the freshwater aquifer is known in the coastal area. Nonetheless, the potential exists for intrusion as a result of increased use of the freshwater resources, particularly in the coastal areas where use of wells for lawn irrigation is increasing. In addition, construction of saltwater canals inland where none previously existed has resulted in intrusion of saltwater into the aquifers in the Venice area.

The hydraulic placement on upland areas of material removed during construction of saltwater canals has resulted in saltwater contamination of aquifers. Leachate and drainage from these spoil piles has infiltrated into the water table and artesian aquifers and locally replaced the freshwater contained in them.

Washover of saline water from the Gulf during storms or high tides has, on occasion, contaminated potable supplies in the water-table aquifer in some of the southern keys. Considerable time likely will be required for natural flushing action to return the ground water to usable quality. 
In some areas saltwater does occur in the aquifer zones that elsewhere contain freshwater. The quality characteristics of Warm Mineral Springs and Little Salt Springs suggest that this water results from upward migration of highly mineralized water from deep aquifer zones, perhaps along fracture systems in the rocks. This water may contaminate shallow aquifers near these springs.

The possibility of direct saltwater intrusion from the Gulf into the freshwater aquifers exists on the Keys where we11s no longer used have not been plugged. Erosion has removed the previously habitable land and the wells are exposed to salt water. If the artesian head in the aquifers is reduced sufficiently to allow water from the Gulf to move down these wells, direct contamination will result. 
Intermixing of water of differing qualities between aquifer zones also occurs in wells when the casing is driven only to the uppermost hard-rock stratum. When the well is not in use, water from a permeable zone with a higher head can migrate into a permeable zone with lower head (Joyner and Sutcliffe, 1967). Thus a well bore can serve as a conduit allowing water of poor quality to intrude a zone containing water of good quality. The enactment of the Sarasota and Manatee County well-drilling codes in 1963 has changed the procedure for drilling wells. Casing installation procedures now require the isolation of zones which contain water of undesirable chemical quality. New procedures have been developed for the drilling of wells in areas where saltwater overlies the freshwater zones (Joyner and Sutcliffe, 1967); this situation is found commonly on the Keys and where salt and other undesirable contaminants are present in the overlying strata. Plugging of unused wells is now required when a replacement well is to be drilled.

Pollution from a variety of sources has deteriorated water quality in some streams and aquifers in the area. For example, effluent from waste-treatment plants is discharged into canals and eventually reaches coastal bays and estuaries. As a result, large offshore areas have been closed to shellfish harvesting. Pollution can be anticipated in the runoff from farmed areas where agricultural chemicals are heavily applied. The residues from these chemicals may be carried by sediment transported in the streams. If new phosphate mines are opened in the eastern part of the area, wastes from mining operations could enter the headwaters of streams now used for public-water supplies, unless specific measures are taken to prevent this (Kaufman, 1969). 


\section{SUMMARY}

In the Myakka River basin area, ground water is obtained both from a water-table aquifer and the artesian aquifer system. Often when adequate quantities of water are available from these aquifers, the quality of the water may not be suitable for many uses. Excessive concentrations of dissolved solids, sulfate, fluoride, or chloride are usually the factors affecting the utilization of ground-water supplies in the area. However, by careful well construction, water of suitable quality for most purposes can be obtained from most of the study area.

Large quantities of ground water of excellent quality can be obtained from al1 aquifers in the northeastern part of the Myakka River basin area. Smal1 quantities of water (usually less than . $50 \mathrm{gal} / \mathrm{min}, 1.9 \mathrm{l} / \mathrm{s}$ ) of suitable quality for domestic use can be obtained from wells developed in the water-table aquifer except where saltwater intrusion has taken place near the coast and in the peninsula south and west of the Myakka River estuary.

Wells tapping artesian zones-1 at depths less than $70 \mathrm{ft}(21 \mathrm{~m})$ and -2 at depths of about $200 \mathrm{ft}(61 \mathrm{~m})$ yield water of suitable quality for domestic use in most areas except in the peninsula west of the Myakka River estuary. In some areas water from zone-2 contains fluoride and sulfate in concentrations greater than 1.6 and $250 \mathrm{mg} / 1$, respectively. 
The water from zone-3 at depths 250 to $450 \mathrm{ft}$ (76 to $137 \mathrm{~km}$ ) is usable for most purposes everywhere except in the peninsula southwest of the Myakka River estuary where the water contains relatively high fluoride, chloride, and sulfate concentrations, in excess of $250 \mathrm{mg} / 1$. Zones -4 at depths 500 to $700 \mathrm{ft}(150$ to $210 \mathrm{~m})$ and -5 at depths of 1,000 to $1,500 \mathrm{ft}(305$ to $457 \mathrm{~m})$ yield large quantities of water but except for the extreme northeastern part of the area, the sulfate and fluoride concentratIons are greater than 250 and $1.5 \mathrm{mg} / 1$.

Most streams in the Myakka River basin area have small drainage basins, short channel lengths, and do not yield high volumes of flow. Many streams, however, yield sufficient flow to represent a potential supply to supplement the needs of the rapidly urbanizing coastal areas. The main limiting factor is the lack of suitable impoundment sites for storing water during the annual dry season. Upper and lower Myakka lakes would provide a continuous supply of $10 \mathrm{Mgal} / \mathrm{d}$ (38 $\mathrm{m} 1 / \mathrm{d}$ ) over a 20-year drought and $6.5 \mathrm{Mgal} / \mathrm{d}(25 \mathrm{~m} 1 / \mathrm{d}$ ) over a 30-year drought if lake stages are maintained at 14 and $10 \mathrm{ft}$ ( 4.3 and $3.0 \mathrm{~m})$ above $\mathrm{msl}$, respectively.

In general, the quality of surface water in the area during normal and high flows is excellent except for high color and temperatures of about $90^{\circ} \mathrm{F}\left(32^{\circ} \mathrm{C}\right)$ during the summer. The concentrations of sulfate, chloride, and fluoride in water of most streams sampled during the study generally met the EPA criteria for drinking water at normal and high flows. During the spring dry season, most of the flow of streams is maintained by ground water which increases the dissolvedsolids, sulfate, chloride, and fluoride concentrations and hardness of the stream water. Near the coast, the chloride concentration of water in tide-affected streams is high. 
About 16.5 billion gallons $(70,000$ million cubic metres) of ground water was used in the Myakka River basin area in 1965. This use averages about $45 \mathrm{Mgal} / \mathrm{d}\left(2 \mathrm{~m}^{3} / \mathrm{s}\right)$. However, because of seasonal patterns of water use, about 40 percent of the annual total use occurs during the dry spring. Sixty-four percent of total ground water use is for irrigation and 35 percent is for public and domestic water supplies. Less than 1 percent of ground water used is for industrial-commercial purposes. The use of surface water was low in 1965, averaging only about $2.5 \mathrm{Mgal} / \mathrm{d}\left(0.1 \mathrm{~m}^{3} / \mathrm{s}\right)$ for public water supp.1y and pasture irrigation.

The water problems in the Myakka River basin area include flooding, inadequate or excessive drainage, inadequate supply of water of suitable quality, and deterioration of the supply by pollution and salt-water intrusion.

About one-third of the land below an altitude of $40 \mathrm{ft}(12 \mathrm{~m})$ is subject to flooding.

One of the most pressing problems in the area is the need for additional supplies of water of suitable quality to meet the requirements of a growing population. This problem could be alleviated in some areas by supplementing the ground-water supply with surface water where the topography is suitable for impoundments. 
The potential exists for saltwater intrusion into freshwater aquifers in coastal areas as ground-water withdrawals increase. The construction of saltwater canals inland has caused some localized saltwater intrusion. The intermixing of water of different quality between aquifers occurs in wells with casing driven only to the first hard-rock stratum. The well bore serves as a conduit which allows water of poor quality from one zone to intrude another zone containing water of better quality. This problem has been corrected for newly constructed and future wells as casing installation procedures stipulated by Sarasota County now require the isolation of zones containing water of poor quality.

Man-made pollution from a variety of sources has deteriorated water quality in streams and aquifers in the area. For example, effluent from public waste-treatment plants is discharged into canals and eventually reaches coastal bays and estuaries. As a result, large offshore areas have been closed to the harvest of shellfish. Runoff from agricultural lands and wastes from phosphatemining operations are potential sources of pollution. 
Applin, P. L., and Applin, E. R., 1944, Regional subsurface stratigraphy of Florida and Southern Georgia: Am. Assoc. Petroleum Geologists Bul1., v. 12, p. 1680-1686.

Barnes, H. H., and Golden, H. G., 1966, Magnitude and frequency of floods in the United States, part 2-B, South atlantic slope and eastern Gulf of Mexico basins, Ogeechee River to Pearl River: U.S. Geol. Survey Water-Supply Paper 1674, 409 p.

Bishop, E. W., 1960, Fresh water resources of Sarasota County, Florida: Board of Sarasota County Commission Research Rept.

Black, A. P., and Brown, Eugene, 1951, Chemical character of Florida's waters: Florida State Board of Conserv., Div. Water Survey, Research Paper 6, $119 \mathrm{p}$.

Clark, W. E., 1964, Possibility of salt-water leakage from proposed intracoastal waterway near Venice, Florida well field: Florida Geo1. Survey Rep. Inv. 38, $33 \mathrm{p}$.

Collins, W. 0., and Howard, C. S., 1928, Chemical character of waters of Florida: U.S. Geol. Survey Water-Supply Paper 596-G, 56 p. Cooke, C. W., 1945, Geology of Florida: Florida Geol. Survey Bull. 29,339 p.

Dalymple, T., 1960, Flood-frequency analyses: U.S. Geo1. Survey Water Supply Paper 1543-A.

Eppert, H. C., 1966, Stratigraphy of the Upper Miocene deposits in Sarasota County, Florida: Tulane Studies in Geology, v. 4, no. 2 , p. 49-61. 
Ferguson, G. E., and Lingham, C. W., Love, S. K., and Vernon, R. 0., 1947, Springs of Florida: Florida Geol. Survey Bu11. 31, 196 p. Flippo, H. N., Jr., and Joyner, B. F., 1968, Low streamflow in the Myakka River basin area in Florida: Florida State Board of Conserv., Div. of Geology, Rept. Inv. 53, 34 p.

Florida State Board of Hea1th, 1960, Some physical and chemical characteristics of selected Florida waters, Jacksonville, F1orida State Board of Health, 108 p.

Florida State Board of Health, 1964, Some physical and chemical characteristics of selected Florida waters (a supplement): Jacksonville, Florida State Board of Health, 54 p. Joyner, B. F., and Sutcliffe, H., Jr., 1967, Salt-water contamination in we11s in the Sara-Sands area in Siesta Key, Sarasota County, Florida: Am. Water Works Assoc. Jour., v. 59, no. 12, p. 1504-1512.

Kaufman, Matthew I., 1969, Generalized distribution and concentration of orthophosphate in Florida streams: Florida Bureau of Geol. Map Series No. 33.

Kohler, M. A., Nordenson, T. J., and Baker, D. R., 1959, Evaporation maps of the United States: U.S. Weather Bureau Tech. Paper 37. Lichtler, W. F., Anderson, W., and Joyner, B. F., 1964, Interim report of the water resources of Orange County, Florida: Florida Geo1 Survey Inf. Circ. 41, $50 \mathrm{p}$.

MacNei1, F. S., 1949, Pleistocene shore lines in Florida and Georgia: U.S. Geo1. Survey Prof. Paper 221-F, 106 p. 
Miller, J. F., 1944, Two to ten-day precipitation for return periods of 2 to 100 years in the contiguous United States: U.S. Weather Bur. Tech. Paper 49.

National Academy of Sciences and National Academy of Engineering, 1973, Water quality criteria 1972 (U.S.) Environmental Protection Agency rept. EPA R3 73033,594 p.

Parker, G. G., and Cooke, C. W., 1944, Late Cenozoic geology of southern Florida, with a discussion of the ground water: Florida Geol. Survey Bu11. 27, 119 p.

Parker, G. G., Ferguson, G. F., Love, S. K., and others, 1955, Water resources of southeastern Florida: U.S. Geol. Survey WaterSupply Paper 1255, 965 p.

Peek, H. M., 1958, Ground-water resources of Manatee County, Florida: Florida Geol. Survey Rept. Inv. 18, 99 p.

Peek, H. M., 1958a, Records of wells in Manatee County, Florida: Florida Geol. Survey Inf. Circ. 19, 199 p.

Pride, R. W., 1973, Estimated use of water in Florida, 1965, Florida Geo1. Survey Map Series 36 .

Sma11y, Wellford and Nalvin, 1961, Sarasota County coastal basins flood-control study: Board of Sarasota County Commissioners, $98 \mathrm{p}$.

Smally, Wellford and Nalvin, 1963, Water supplies of Sarasota County: Board of Sarasota County Commissioners, 122 p. 
Smith and Gillespie, 1960, Interim report on ground-water studies for Sarasota, Florida: C.ty of Sarasota, 20 p.

Stewart, H. G., 1966, Ground-water resources of Polk County, Florida:

Florida Beo1. Survey Rept. Inv. 44, 170 p.

Stringfield, V. T., 1933, Ground-water investigations in Florida:

Florida Geol. Survey Bull. 11, p. 1-33.

Stringfield, V. T., 1936, Artesian water in the Florida peninsula:

U.S. Geo1. Survey Water-Supply Paper 773-C, p. 115-195.

Stringfield, V. T., 1966, Artesian water in Tertiary Limestone in the southeastern states, U.S. Geol. Survey Prof. Paper 517, 226 p.

Sutcliffe, H., Jr., and Joyner, B. F., 1966, Packer testing in water wells in Sarasota County, Florida: Ground water, v. 4, no. 2 p. 23-27.

Sutcliffe, H., Jr., and Joyner, B. F., 1968, Test well exploration in the Myakka River basin area, Florida: Florida State Board of Conserv. Div. of Geology Inf. Circ. 56, 61 p.

U. S. Army Corps of Engineers, 1961, Analysis of hurricane problems in coastal areas of Florida: U.S. Army Corps of Engineers, Jacksonville.

U. S. Soil Conservation Service, 1961, Work plan for Sarasota West Coast Watershed: U.S. Dept. Agriculture.

U. S. Soi1 Conservation Service, 1965, Work plan for Big Slough watershed: U.S. Dept. Agriculture.

Wander, I. W., and Reitz, H. J., 1951, The chemical composition of irrigation water used in Florida sitrus groves: Florida Univ. Agr. Exp. Sta. Bu1l. 480, 7 p. 
In this report, wells are referred to by a local number, serially from 1 through 67. The U.S. Geological Survey Site Identification Number is a 15-digit number based on the latitude and longitude coordinates of the well site. The table below shows the Site Identification number for each well mentioned in this report.

\section{WELL AND SITE IDENTIFICATION NUMBERS}

1. $264323 \mathrm{~N} 0821530.1$

2. $264923 \mathrm{~N} 0820137.1$

3. $265017 \mathrm{~N} 0821537.1$

4. 265557 N0821522.1

5. $265612 \mathrm{~N} 0821104.1$

6. $265713 \mathrm{~N} 0822057.1$

7. 265742N0822103.1

8. 265922N0820456.1

9. $265944 \mathrm{~N} 0821754.1$

10. 270133N0820346.1

11. 270133N0820346.2

12. 270137 N0822353.1

13. $270247 \mathrm{~N} 0821619.1$

14. $270422 \mathrm{~N} 0822447.1$

15. 270542N0822616.1

16. 270542N0822618.1

17. 270714 N0821552.1

18. 270728N0822328.1

19. 270731N0822714.1

20. 270927 N0820609.1

21. 270931N0822529.1

22. 270938N0820756.1
23. 271118N0822853.1 24. 271134N0820922.1 25. 271134N0820922.2 26. 271135N0822802.1 27. $271213 \mathrm{~N} 0820559.1$ 28. 271213N0822908.1 29. 271420NO822257.1 30. 271456 N0822309.2 31. 271608N0822802.1 32. $271611 \mathrm{~N} 0820502.1$ 33. $271614 \mathrm{NO} 823043.1$ 34. $271659 \mathrm{~N} 0823130.1$ 35. $271757 \mathrm{~N} 0822413.1$ 36. 271821 N0821551.1 37. 271827 N0822024.1 38. 271832NO820648.1 39. $271832 \mathrm{NO} 820648.2$ 40. $271922 \mathrm{~N} 0823407.1$ 41. 271938N0822518.1 42. $272004 \mathrm{~N} 0822818.2$ 43. $272007 \mathrm{~N} 0821753.1$ 44. $272021 \mathrm{~N} 0823536.1$
45. 272022N0822312.1 46. 272034N0821452.1 47. 272036N0822846.1 48. 272041N0823223.1 49. 272047N0821144.1 50. 272047 N0822915.1 51. 272054N0822936.1 52. 272102N0821006.1 53. 272122N0823308.1 54. 272128N0822003.1 55. 272256N0821635.1 56. 272258N0821953.1 57. 272301NO821941.1 58. 272308N0821618.1 59. 272356N0821813.1 60. 272438N0823252.1 61. 272523N0820336.1 62. $272706 \mathrm{~N} 0822255.1$ 63. 272728N0821515.1 64. 272731N0820546.1 65. 272735N0820834.1 66. 272938N0820834.1 67. 273307N0820351.1 


\section{.}




$$
\text { . }
$$



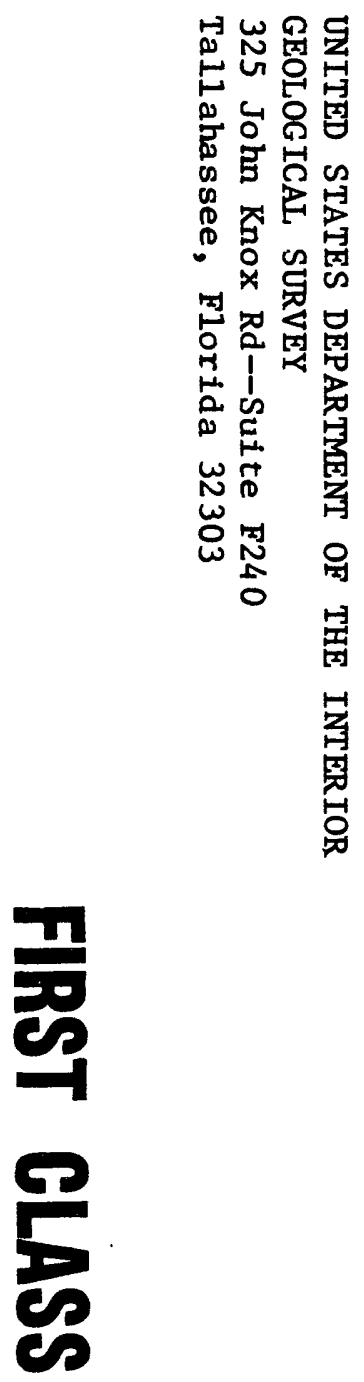

苟的嵒

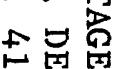

$D$

,

罢界

s

搨

붑

퍼

晕 